\title{
COURTING Confusion? THREE RECENT AlBERTA CASES ON EQUALITY RIGHTS POST-KAPP
}

\author{
JONNETTE WATSON HAMILTON AND JENNIFER KOSHAN*
}

This article examines current confusion surrounding how courts are to analyze challenges brought under s. 15 of the Canadian Charter of Rights and Freedoms. The authors begin with a review of the 2008 Supreme Court of Canada decision in R. v. Kapp, which gave s. 15(2) independent status to shield ameliorative laws, programs, and activities from the finding of discrimination, but left the application of $s$. 15(1) unclear.

The authors then articulate how three recent Alberta cases on equality post-Kapp illustrate the new uncertainty surrounding how courts are to address equality rights. Through an analysis of the Supreme Court's 2009 decision in Ermineskin Band and Nation v. Canada, and subsequent decisions of the Alberta Court of Appeal in Morrow v. Zhang and Cunningham v. Alberta (Aboriginal Affairs and Northern Development), this article explores the Supreme Court's failure to adequately guide lower courts and tribunals on how to apply s. 15 post-Kapp. For example, a framework for reconciling the new role of s. 15(2) and claims of under-inclusive ameliorative programs has yet to be developed. Further, the authors argue that the guidance that has been delivered has improperly narrowed the definition of discrimination to stereotyping and prejudice.
Cet article examine la confusion qui existe actuellement autour de la manière dont les cours doivent analyser les défis soulevés en vertu de l'article 15 de la Charte canadienne des droits et libertés. Les auteurs commencent par une revue de la décision R. c. Kapp de la Cour suprême du Canada accordant le statut indépendant à l'article 15(2) pour protéger les lois, programmes ou activités destinés à améliorer la situation d'individus ou de groupes défavorisés, mais n'étant pas clair sur la portée de l'application de l'article 15(1).

Les auteurs passent ensuite à trois causes récentes en Alberta portant sur l'égalité, ayant eu lieu après l'affaire Kapp, pour illustrer la nouvelle incertitude qui règne au sujet de la manière que les cours abordent les droits à l'égalité. Au moyen de l'analyse de la décision Bande et nation indiennes d'Ermineskin c. Canada, 2009 de la Cour suprême du Canada et des décisions subséquentes de la Cour d'appel de l'Alberta, à savoir Morrow c. Zhang et Cunningham c. Alberta (Affaires autochtones et Développement du Nord), cet article explore le manque de la Cour suprême de guider correctement les instances inférieures sur l'application de l'article 15 après la décision Kapp. Par exemple, un cadre de réconciliation du nouveau rôle de l'article 15(2) et les revendications des programmes améliorateurs d'application restreinte ne sont pas encore développés. En outre, les auteurs font valoir que les directives émises ont mal restreint la définition de discrimination à la stéréotypie et au préjudice.

\section{TABLE OF ConTENTS}

I. INTRODUCTION . . . . . . . . . . . . . . . . . . . . 928

II. THE POST-LAW APPROACH? R. V. KAPP . . . . . . . . . . . . . . . . . 929

III. THE END OF LAW? ERMINESKIN INDIAN BAND

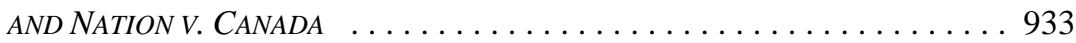

IV. THE RETURN OF LAW? MORROW V. ZHANG . . . . . . . . . . . . . . 938

V. THE EVOLUTION OF LAW? CUNNINGHAM V. ALBERTA

(ABORIGINAL AFFAIRS AND NORTHERN DEVELOPMENT) . . . . . . . . . 944

Associate Professors, Faculty of Law, University of Calgary. This article is based on a series of comments originally posted on ABlawg, online: ABlawg: The University of Calgary Faculty of Law Blog on Developments in Alberta Law <http://www.ABlawg.ca>. The authors wish to thank the anonymous reviewers of this article for their helpful comments. 


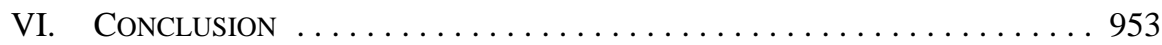

\section{INTRODUCTION}

After the Supreme Court of Canada handed down its decision in Kapp ${ }^{1}$ in June 2008, there were questions about whether the Court had changed the legal framework for analyzing challenges brought under s. 15(1) of the Canadian Charter of Rights and Freedoms. ${ }^{2}$ Kapp had clearly changed the approach to s. 15(2), granting it independent status to protect ameliorative laws, programs, and activities. However, on the topic of s. 15(1), the Court had sent mixed signals about its future approach. The message sent by the Supreme Court's February 2009 decision in Ermineskin ${ }^{3}$ seems much clearer than Kapp; the legal framework for analyzing s. 15(1) claims will be very different than it has been for the past decade.

However, two subsequent decisions of the Alberta Court of Appeal, Morrow ${ }^{4}$ and Cunningham, ${ }^{5}$ illustrate that there is continued uncertainty about the proper approach for courts to take in equality rights claims. Morrow and Cunningham purport to acknowledge the impact of Kapp and Ermineskin. Yet these cases return to the approach taken in the Supreme Court's previous leading decision on s. 15(1), Law, ${ }^{6}$ in varying and sometimes problematic degrees. ${ }^{7}$

This article will analyze these three Alberta s. 15 decisions with a view to showing how they exemplify ongoing confusion and difficulties with the judicial approach to equality. ${ }^{8}$ Before doing so, we will briefly review the importance of Kapp in order to provide background for the discussion to follow. Our analysis will show that there continue to be problems with the Supreme Court's approach to s. 15(1). The Court has failed to give adequate guidance to lower courts and tribunals ${ }^{9}$ on how to apply s. 15(1) post-Kapp, and the

R. v. Kapp, 2008 SCC 41, [2008] 2 S.C.R. 483 [Kapp].

Part I of the Constitution Act, 1982, being Schedule B to the Canada Act 1982 (U.K.), 1982, c. 11 [Charter].

Ermineskin Indian Band Nation v. Canada, 2009 SCC 9, [2009] 1 S.C.R. 222 [Ermineskin].

Morrow v. Zhang, 2009 ABCA 215, 454 A.R. 221 [Morrow (C.A.)].

Cunningham v. Alberta (Minister of Aboriginal Affairs and Northern Development), 2009 ABCA 239,

457 A.R. 297, leave to appeal to S.C.C. granted, [2010] S.C.C.B. at 302 [Cunningham (C.A.)].

Law v. Canada (Minister of Employment and Immigration), [1999] 1 S.C.R. 497 [Law].

It is not unusual for lower courts to respond slowly to a new direction from the Supreme Court. After that Court's first s. 15 equality rights decision in Andrews v. Law Society of British Columbia, [1989] 1 S.C.R. 143 [Andrews], lower courts resisted the implementation of its approach by attempting to narrow Andrews, distinguish it, or by quoting from it without applying it: see M. David Lepofsky, "The Canadian Judicial Approach to Equality Rights: Freedom Ride or Roller Coaster?” (1992) 55 Law \& Contemp. Probs. 167 at 179 . What was perhaps unusual was the alacrity with which lower courts adopted the Law framework.

$8 \quad$ We take a primarily doctrinal approach in this paper, although we do discuss some issues pertaining to equality theory (e.g. how to conceptualize the harms of discrimination, see text accompanying notes 44, $62,116,148)$.

9 The application of the Law framework to complaints of discrimination by human rights tribunals has been controversial, mainly because of Law's requirement that a complainant establish an injury to his or her human dignity: see e.g. Vancouver Rape Relief Society v. Nixon, 2005 BCCA 601, 47 B.C.L.R. (4th) 203 at para. 35 [Nixon]. For commentary on the issue, see Christine Boyle, "The AntiDiscrimination Norm in Human Rights and Charter Law: Nixon v. Vancouver Rape Relief' (2004) 37 U.B.C. L. Rev. 31; Andrea Wright, "Formulaic Comparisons: Stopping the Charter at the Statutory Human Rights Gate,” in Fay Faraday, Margaret Denike \& M. Kate Stephenson, eds., Making Equality Rights Real: Securing Substantive Equality under the Charter (Toronto: Irwin Law, 2006) 409; for applications of Kapp in the human rights context, see Van der Smit v. Alberta (Human Rights and Citizenship Commission), 2009 ABQB 121, 4 Alta. L.R. (5th) 372 at paras. 58-72 (a human rights complaint unsuccessfully challenging the provincial producer marketing board's Sunday milk collections as discriminatory on religious grounds); Ontario (Director, Disability Support Program) $v$. 
guidance it has provided arguably narrows the meaning of discrimination to include only stereotyping and prejudice. Even within the narrow context of stereotyping, which arises in each of the three cases we examine, it is difficult to discern a consistent approach amongst the decisions. Further, Cunningham considers s. 15(2) in the context of underinclusive ameliorative programs, a context in which the Supreme Court also failed to provide guidance in Kapp. We conclude with our thoughts on important first principles for equality claims under s. 15 of the Charter.

\section{The Post-Law Approach?}

\section{R. V. KAPP}

The Kapp decision considered a challenge to the federal government's Aboriginal Fisheries Strategy (AFS), a strategy aimed at enhancing Aboriginal involvement in commercial fisheries. As part of the challenged Pilot Sales Program (PSP), the Minister of Fisheries and Oceans issued a communal fishing licence to the Musqueam, Tsleil-Wauthuth, and Tsawwassen First Nations in British Columbia, allowing them to fish exclusively for a 24-hour period in August 1998 for food, social, and ceremonial purposes, and to sell their catch. In response, a group of commercial fishermen who were excluded from the fishery during the 24-hour period, and who were organized by the British Columbia Fisheries Survival Coalition, conducted a protest fishery for the purpose of bringing a constitutional challenge to the communal licence. Charged with fishing at a prohibited time, the accused commercial fishermen sought declarations that the AFS, the regulations setting up the PSP and the communal fishing licence discriminated on the basis of race and were thus unconstitutional under s. 15 of the Charter.

In its decision upholding the AFS and PSP, the Supreme Court seemed to leave no doubt that Andrews, the Court's first equality rights decision, is henceforth to be considered the leading case on s. 15(1). The Court's decision in Law — the leading decision from 1999 to 2008 - was relegated to a supporting role. Andrews, the Court asserted in Kapp, "set the template for this Court's commitment to substantive equality." 10 The ascendancy of Andrews and its two-part test is clearest in the following passage from Kapp:

\footnotetext{
The template in Andrews, as further developed in a series of cases culminating in Law v. Canada (Minister of Employment and Immigration) ... established in essence a two-part test for showing discrimination under s. 15(1): (1) Does the law create a distinction based on an enumerated or analogous ground? (2) Does the distinction create a disadvantage by perpetuating prejudice or stereotyping? These were divided, in Law, into three steps, but in our view the test is, in substance, the same. ${ }^{11}$
}

Tranchemontagne (2009), 95 O.R. (3d) 327 at paras. 85-94 (Ont. Sup. Ct. J.) [Tranchemontagne] (a human rights complaint successfully challenging the complainants' exclusion from the Ontario Disability Support Program on the basis that they were disabled solely by their alcoholism. Tranchemontagne is currently before the Ontario Court of Appeal).

10 Supra note 1 at para. 14. The Court also reaffirmed its commitment to substantive equality in Kapp, writing that "[a]n insistence on substantive equality has remained central to the Court's approach to equality claims” (at para. 15).

11 Ibid. at para. 17. We include a chart summarizing the various s. 15 tests in Appendix A, below. 
Of note is the Court's assertion that the three-step test in Law is the same in substance as the two-part test in Andrews. Apparently, Law had merely divided Andrews' first part into two questions, separating out the distinction drawn from the ground on which it was drawn. ${ }^{12}$

The Court in Kapp had little to say about Andrews' first step. It did note that Law had been criticized for allowing “the formalism of some of the Court's post-Andrews jurisprudence to resurface in the form of an artificial comparator analysis focussed on treating likes alike.»13 Aside from this acknowledgement of the criticism, however, the Court said nothing about comparator groups. This left up in the air the issues surrounding comparator groups that had been raised in the academic literature the Court cited, ${ }^{14}$ and the impact of cases such as Hodge $^{15}$ and Auton, ${ }^{16}$ where the Supreme Court's choice of comparators precluded the success of the equality claims.

The Supreme Court had much more to say about Andrews' second step in Kapp. This step - analyzing whether the distinction based on an enumerated or analogous ground identified in step one amounts to discrimination — is often the most difficult part of a s. 15(1) analysis. In Andrews, according to Kapp, discrimination was defined by two concepts:

(1) the perpetuation of prejudice or disadvantage to members of a group on the basis of personal characteristics identified in the enumerated and analogous grounds; and

(2) stereotyping on the basis of these grounds that results in a decision that does not correspond to a claimant's or group's actual circumstances and characteristics. ${ }^{17}$

However, in Law, discrimination had been redefined

in terms of the impact of the law or program on the "human dignity" of members of the claimant group, having regard to four contextual factors: (1) pre-existing disadvantage, if any, of the claimant group; (2) degree of correspondence between the differential treatment and the claimant group's reality; (3) whether the law or program has an ameliorative purpose or effect; and (4) the nature of the interest affected. ${ }^{18}$

This assertion of "same in substance" has been used by some lower courts to justify their continued application of the Law framework post-Kapp without any modifications: see e.g. Downey v. Nova Scotia (Workers' Compensation Appeals Tribunal), 2008 NSCA 65, 267 N.S.R. (2d) 364 at para. 44 [Downey] (challenging regulations of the workers' compensation legislation that placed a 6 percent cap on painrelated impairments).

$13 \quad$ Supra note 1 at para. 22.

14 Sophia Reibetanz Moreau, “Equality Rights and the Relevance of Comparator Groups” (2006) 5 J.L. \& Equality 81; Daphne Gilbert \& Diana Majury, “Critical Comparisons: The Supreme Court of Canada Dooms Section 15” (2006) 24 Windsor Y.B. Access Just. 111; Beverley Baines, “Equality, Comparison, Discrimination, Status” in Faraday, Denike \& Stephenson, supra note 9 at 73; Dianne Pothier, “Equality as a Comparative Concept: Mirror, Mirror, on the Wall, What's the Fairest of Them All?” in Sheila McIntyre \& Sanda Rodgers, eds., Diminishing Returns: Inequality and the Canadian Charter of Rights and Freedoms (Markham, Ont.: LexisNexis Canada, 2006) 135.

15 Hodge v. Canada (Minister of Human Resources Development), 2004 SCC 65, [2004] 3 S.C.R. 357 [Hodge].

16 Auton (Guardian ad litem of) v. British Columbia (Attorney General), 2004 SCC 78, [2004] 3 S.C.R. 657 [Auton].

$17 \quad$ Kapp, supra note 1 at para. 18.

18 Ibid. at para. 19 [footnotes omitted]. 
In Kapp, the Court acknowledged the difficulties created by "the attempt in Law to employ human dignity as a legal test." 19 Human dignity, while still "an essential value underlying” s. $15,{ }^{20}$ was admitted to be "an abstract and subjective notion that ... [could] become confusing and difficult to apply"21 and, worse, "an additional burden on equality claimants." 22 That is all the Court had to say about human dignity in Kapp, however. Its role in future s. 15(1) jurisprudence was left unsettled.

The Supreme Court was more specific in Kapp about the four contextual factors set out in Law by which impact on human dignity was to be assessed. Those four factors, the Court asserted, "are based on and relate to the identification in Andrews of perpetuation of disadvantage and stereotyping as the primary indicators of discrimination." ${ }^{23}$ Law's factors one and four went to Andrews' perpetuation of disadvantage and prejudice, it was said, while Law's second factor dealt with stereotyping. The third factor was now subsumed in the s. 15(2) analysis, but might still have a role in determining whether the effect of the law or program was to perpetuate disadvantage. ${ }^{24}$ With this amalgamation in Kapp of Law's four contextual factors to the two concepts of discrimination attributed to Andrews, Law appeared to continue to have a role in future analyses under s. 15(1):

\footnotetext{
Viewed in this way, Law does not impose a new and distinctive test for discrimination, but rather affirms the approach to substantive equality under s. 15 set out in Andrews and developed in numerous subsequent decisions. The factors cited in Law should not be read literally as if they were legislative dispositions, but as a way of focussing on the central concern of s. 15 identified in Andrews - combatting discrimination, defined in terms of perpetuating disadvantage and stereotyping. ${ }^{25}$
}

The future role of Law was left in question, however, because the Supreme Court did not undertake a full s. 15(1) analysis in Kapp itself; such an analysis was found to be unnecessary. As mentioned, s. 15(2) was the major concern of the Court's ruling in Kapp. According to the Court, while s. 15(1) focuses on "preventing governments" from discriminating, s. 15(2) focuses on "enabling governments to pro-actively combat existing discrimination through affirmative measures."26 Departing from previous cases such as Lovelace ${ }^{27}$ where s. $15(2)$ was used as an interpretive aid for s. 15(1), the Court held that a law or program will not violate equality rights where "the government can demonstrate that: (1) the program has an ameliorative or remedial purpose; and (2) the program targets a disadvantaged group identified by the enumerated or analogous grounds."28 This assessment is made after step one in s. 15(1) - that is, after a finding of a distinction based on a protected ground is made, and before considering whether there has been discrimination

Ibid. at para. 21 [emphasis in original].

Ibid.

Ibid. at para. 22.

Ibid. [emphasis in original].

Ibid. at para. 23.

Ibid.

Ibid. at para. 24. As we note below, the Court is not clear in its use of "perpetuation" in relation to disadvantage, prejudice, and stereotyping (see infra note 84). And, as shown in this passage, the Court is not consistent in its use of the terms disadvantage, prejudice, and stereotyping and their relation to discrimination either, using different combinations of these terms at different points in the judgment. Ibid. at para. 25 [emphasis in original].

Lovelace v. Ontario, 2000 SCC 37, [2000] 1 S.C.R. 950 [Lovelace].

Kapp, supra note 1 at para. 41 . 
under the second step. ${ }^{29}$ Because the Court in Kapp found that the PSP at issue was ameliorative in the sense covered by s. 15(2), it never did apply its "new" approach to discrimination to the facts of the case.

There initially was quite a bit of positive response to the Supreme Court's return to Andrews in Kapp. ${ }^{30}$ It is true that Andrews was groundbreaking in its rejection of a formal equality analysis in favour of substantive equality. ${ }^{31}$ However, Andrews was fairly introductory in terms of what a substantive equality analysis would look like. It would be a comparative and contextual analysis, and one that focused on both the purpose and effects of the law, but what else it would be was not that clear. We should recall that there was academic criticism of Andrews when it was released, ${ }^{32}$ as well as controversies over the application of Andrews and its approach to equality rights even before Law. $^{33}$

Ibid. at para. 40 .

See e.g. Bruce Ryder, “R. v. Kapp: Taking Section 15 Back to the Future” (2 July 2008), online: The Court <http://www.thecourt.ca/2008/07/02/r-v-kapp-taking-section-15-back-to-the-future/>; Debra M. McAllister, “Overview: Supreme Court of Canada Charter Decisions” (2008-2009) 25 N.J.C.L. 1 at 1213; Ranjan K. Agarwal \& Rahool P. Agarwal, “R. v. Kapp”, Case Comment, (2009) 2 J. Parliamentary \& Pol. L. 335; Michael H. Morris \& Joseph K. Cheng, "Lovelace and Law Revisited: The Substantive Equality Promise of Kapp” (2009) 47 Sup. Ct. L. Rev. (2d) 281. For critical opinions of Kapp’s approach to s. 15, see Dianne Pothier, "Kapp gives affirmative action programs wide margins" (19 September 2008) 28:19 The Lawyers Weekly; Diana Majury, "Equality Kapped; Media Unleashed” (2009) 27 Windsor Y.B. Access Just. 1. See also Sophia Moreau, " $R$. v. Kapp: New Directions for Section 15” (2008-2009) 40 Ottawa L. Rev. 283 (arguing that Kapp's novel interpretations of s. 15(1) and s. 15(2) can be seen as promising provided that the Court offers a more expansive interpretation of the idea of "disadvantage" under s. 15(1) and qualifies its highly deferential approach under s. 15(2) in certain key ways).

Justice McLachlin, as she then was, had taken a formal equality approach at the B.C. Court of Appeal in Andrews: see Andrews v. Law Society of British Columbia (1986), 2 B.C.L.R. (2d) 305 (C.A.).

See e.g Marc Gold, "Comment: Andrews v. Law Society of British Columbia” (1989) 34 McGill L.J. 1063 at 1070-73 (discussing the difficulty, if not the impossibility, of holding a middle ground between an approach that requires all distinctions be justified and one that imports s. 1 into s. 15); Richard Moon, "A Discrete and Insular Right to Equality: Comment on Andrews v. Law Society of British Columbia" (1989) 21 Ottawa L. Rev. 563 (discussing the indeterminacy of the approach set out in Andrews); Jody Freeman, "Justifying Exclusion: A Feminist Analysis of the Conflict between Equality and Association Rights” (1989) 47 U.T. Fac. L. Rev. 269 at 279-81 (expressing doubts about lower courts’ ability to apply the Andrews' approach to s. 15 because its content and parameters were not adequately delineated); Diana Majury, "Equality and Discrimination According to the Supreme Court of Canada" (1990-1991) 4 C.J.W.L. 407 at 426 (noting that McIntyre J.’s definition of discrimination is neutral about whether the group is dominant or subordinate and fails "to recognize that concepts such as "merit" and "capacity" have consistently been used to exclude women, people with disabilities, people of colour, and ethnic minorities"); Dale Gibson, "Analogous Grounds of Discrimination Under the Canadian Charter: Too Much Ado About Next to Nothing” (1991) 29 Alta. L. Rev. 772 (surveying the "grossly confused state" of lower courts' approaches to "analogousness" following Andrews' restriction of constitutionally prohibited forms of discrimination to the grounds listed in s. 15(1) or those analogous thereto); J. Donald C. Galloway, “Three Models of (In)Equality” (1993) 38 McGill L.J. 64 at 67 (critiquing the Court's failure to make clear whether equality and discrimination are conceptually independent).

See e.g. the trilogy of Miron v. Trudel, [1995] 2 S.C.R. 418; Egan v. Canada, [1995] 2 S.C.R. 513; Thibaudeau v. Canada, [1995] 2 S.C.R. 627. Even earlier than the trilogy, however, the Supreme Court interpreted Andrews to mean different things: see e.g. R. v. Turpin, [1989] 1 S.C.R. 1296 [Turpin], where the Court focused on the meaning of the equality rights protected under s. 15(1). According to Wilson J. for a unanimous Court, "[i]t is only when one of the four equality rights has been denied with discrimination that the values protected by s. 15 are threatened and the court's legitimate role as the protector of such values comes into play" (at para. 48). See also R. v. Swain, [1991] 1 S.C.R. 933 at $940-$ 41 [emphasis added], where Lamer C.J.C. described the test as follows:

The court must first determine whether the claimant has shown that one of the four basic equality rights has been denied (i.e., equality before the law, equality under the law, equal protection of the law and equal benefit of the law). This inquiry will focus largely on whether the law has drawn a distinction (intentionally or otherwise) between the claimant and others, based on personal characteristics. Next, the Court must determine whether the denial can be said to result in "discrimination". This second inquiry will focus largely on whether the differential treatment has the effect of imposing a burden, obligation or disadvantage not imposed upon others, or of withholding or limiting access to opportunities, benefits and advantages available to others. 
Perhaps it is not surprising that lower court decisions after Kapp suggest that, aside from formulating the test as a two-part test instead of a three-part test, Kapp was having little impact on the analysis of s. 15(1) claims. All of the lower courts which dealt with challenges under s. 15(1) in the seven-and-one-half months between the Kapp and Ermineskin decisions have used the two-part test set out in Kapp..$^{34}$ However, most also used the concept of human dignity and Law's four contextual factors in the second step. ${ }^{35}$ The following section will explore how the Supreme Court's subsequent s. 15(1) decision in Ermineskin should have changed the impact of Kapp.

\section{THE END OF LAW? \\ ERMINESKIN INDIAN BAND AND NATION V. CANADA}

The Supreme Court of Canada's February 2009 decision in Ermineskin deals with the federal government's treatment of oil and gas royalties under the Indian Act. ${ }^{36}$ Although the decision has not received much attention as a s. 15(1) case, in our opinion this is a mistake. Ermineskin is the first Supreme Court case to apply the analytical framework set out in Kapp, and the unanimous Court went out of its way to explain its reasons for dismissing the s. 15(1) claim on a substantive, rather than procedural basis. ${ }^{37}$

The Ermineskin and Samson Nations, two Treaty 6 bands, were entitled to royalties from the production of oil and gas on the Pigeon Lake and Samson Reserves in Alberta. The Crown held the royalties in trust for the bands in the Consolidated Revenue Fund, and the bands were paid interest on those trust funds at the rate paid for long-term government bonds. The Ermineskin and Samson Nations argued that the Crown should have invested the royalties so as to provide them with higher rates of return or, alternatively, that the Crown should have transferred the funds to the bands to invest themselves, something the Crown refused to do absent proof of a financial management plan. The Crown's failure to invest or transfer was, according to the bands, a breach of its fiduciary duties and amounted to unjust

The "Andrews test” relied upon in Kapp thus appears to take into account some of the subsequent interpretation of Andrews in other Supreme Court cases. However, a full analysis of the interpretation of Andrews is beyond the scope of this article.

$34 \quad$ See Hartling v. Nova Scotia (Attorney General), 2009 NSSC 2, 278 N.S.R. (2d) 112 at para. 17 [Hartling] (challenging the constitutionality of statutory and regulatory caps on accident victims' recovery of non-pecuniary damages for "minor injuries”); C.-W.(C.) v. Ontario Health Insurance Plan (General Manager) (2009), 95 O.R. (3d) 48 at para. 104 (Sup. Ct. J.) (challenging a health insurance legislative requirement for prior written approval for payment of medical expenses provided outside Canada when those services were not available in Ontario); Withler v. Canada (Attorney General), 2008 BCCA 539, 87 B.C.L.R. (4th) 197 at para. 155, leave to appeal to S.C.C. granted, [2009] 1 S.C.R. xiv [Withler] (challenging Canadian Forces and public service superannuation provisions that reduced supplementary death benefits payable to surviving spouses based on the age the pension plan's participants reached prior to their deaths); Confédération des syndicats nationaux c. Québec (Procureur général), 2008 QCCS 5076, [2008] R.J.D.T. 1477 at paras. 326-27 (challenging laws prohibiting the unionization of home day care providers and family home care providers); Downey, supra note 12 at para. 44.

35 Even though Withler, ibid. at paras. 159-60, and Hartling, ibid. at para. 19, noted that the Supreme Court in Kapp had moved away from Law's insistence that discrimination be defined in terms of the impact of the law or program on human dignity, they both still applied Law's four contextual factors, as did the court in Downey, ibid.

$36 \quad$ R.S.C. 1985 , c. I-5.

Supra note 3 at para. 187. 
enrichment. ${ }^{38}$ Of more interest for our purposes, the bands also challenged several sections of the Indian Act that provided for the management of "Indian moneys." To the extent those provisions precluded the Crown from investing or transferring the royalties, the bands argued that they violated the Charter's equality guarantee.

While Kapp left some questions unanswered about its impact on s. 15(1), the analytical approach to that section clearly appears changed in Ermineskin. The Supreme Court did not overrule Law in Kapp; in fact, it seems to have gone out of its way to avoid saying the test set out in Law was wrong. But there is no reference to Law in Ermineskin. ${ }^{39}$ The phrase "human dignity" is never mentioned and none of the four contextual factors from Law are used. Instead, context is now said to be the larger social, political, and legal context of the impugned legislation. ${ }^{40}$ The Ermineskin decision should therefore provide a strong signal to lower courts that the Law framework for analyzing an equality challenge should no longer be used. ${ }^{41}$

The first part of the Andrews test, as restated by Kapp, ${ }^{42}$ asks whether the law creates a distinction based on an enumerated or an analogous ground. The Court said very little about this part of the test in Kapp, but it says even less in Ermineskin. In the latter case, the Court merely states that the first part of the test requires a determination of whether the law creates a distinction based on an enumerated or analogous ground. ${ }^{43}$ There is no elaboration.

This lack of direction, given the acknowledged criticism about comparator groups in Kapp, is disappointing. ${ }^{44}$ Even more concerning, however, is the way the Supreme Court

For analysis of the issues relating to fiduciary duty and unjust enrichment, see Nigel Bankes, "The Crown has neither the power nor the duty to invest Indian monies: The use of legislation to limit trust duties” (20 February 2009), online: ABlawg: The University of Calgary Faculty of Law Blog on Developments in Alberta Law < http://ablawg.ca/2009/02/20/the-crown-has-neither-the-power-nor-theduty-to-invest-indian-monies-the-use-of-legislation-to-limit-trust-duties/>. The only equality cases the Court relies upon in Ermineskin, supra note 3, are Andrews, supra note 7, and Turpin, supra note 33.

$40 \quad$ Ermineskin, ibid. at para. 193, citing Turpin, ibid. at 1331.

41 In the provincial Court of Appeal cases decided after Kapp, but before Ermineskin, the judgments appealed from were based on the pre-Kapp law and used the Law analytical framework. See cases cited at supra note 34. However, there was no use of the Law analytical framework in the lower court decisions in Ermineskin, perhaps making it easy for the Supreme Court to ignore Law. In the Federal Court, Teitelbaum J. held that the bands were not individuals for the purposes of the Charter and that they therefore had no standing to bring a s. 15(1) claim: see Ermineskin Indian Band and Nation v. Canada, 2005 FC 1623, 269 F.T.R. 188 at paras. 319-21. In the Federal Court of Appeal, the majority dismissed the bands' arguments regarding s. 15(1) of the Charter: see Ermineskin Indian Band and Nation v. Canada, 2006 FCA 415, [2007] 3 F.C.R. 245 at paras. 129-34. The majority held that even if the individual band members had standing, they would have no interest to enforce because their claims related to the management of band property and not a personal right. Justice Sexton, writing in dissent, did not find it necessary to deal with the s. 15(1) issue because he concluded that the Crown had breached its duty to invest. Nevertheless, he did comment that in his view, the interpretation of the legislation adopted by the trial judge would result in a violation of s. 15(1) because the legislation subjected Indians to inferior and discriminatory treatment based on their Indian status and membership in a band, as compared to non-Indians. On the standing point, Sexton J.A. indicated that, because the action was a representative action brought on behalf of all individual members of the bands, there was standing to maintain the claim (at paras. 297-311).

42 Supra note 1 at para. 17. The Supreme Court uses the language of "Andrews, restated in Kapp" in Ermineskin, supra note 3 at para. 188. For ease of reference, and because we do not necessarily agree that Kapp simply restates Andrews (see supra note 33), we will hereinafter refer to this as the Kapp test.

43 Ermineskin, ibid.

44 The lack of direction on comparators is not surprising, however, if one accepts the argument that stereotyping and prejudice - the current focus of s. 15(1) - are not inherently comparative concepts: see Sophia R. Moreau, “The Wrongs of Unequal Treatment” (2004) 54 U.T.L.J. 291. Moreau defines a stereotype as "any generalization or classification that one group of people treats as though it captured 
applies the first part of the test to the facts in Ermineskin. According to the Court, the appellants had argued that, as "Indians," they had "been deprived by the Indian Act of the rights ... available to non-Indians whose property is held in trust by the Crown." 45 The Court found that the first requirement of the test was satisfied, as the impugned legislation created "a distinction between Indians and non-Indians because the legislation only applies to Indians." ${ }^{46}$ This appears to be a very superficial comparison rather than a description of a distinction based on an enumerated or analogous ground, and one that does not accept the appellants' comparison between themselves and non-Indians whose property is held in trust by the Crown. However, when the Court makes comparisons with other groups in the second part of the Kapp test, they change the group from simply "non-Indians" to "other trust relationships where risk and financial returns are generally the only considerations, and where there is little concern with the trustee having complete control and discretion." ${ }^{47}$ The change is unacknowledged and unexplained, perhaps because it is merely part of the Court's look at "the broader context." 48

The Samson Nation had argued that three comparator groups were relevant: (1) "[a]ll other trust beneficiaries who are not 'Indians' or 'Bands of Indians'; (2) [a]ll others for whom the federal Crown acts as statutory fiduciary or trustee; and (3) [a]ll other beneficiaries of a federally-regulated fund managed by a fiduciary or trustee." ${ }^{9}$ They further argued that members of these comparator groups had the right to have their moneys invested or earn a maximum rate of return. In light of the Court's holding that the Indian Act did not preclude the Crown from transferring the funds to the bands for investment provided that such transfers were in the bands' best interests, ${ }^{50}$ another relevant comparator would have been beneficiaries who are not obliged to convince the Crown that they have a financial management plan before a transfer will be made. Arguably, the failure to identify and apply an appropriate comparator contributes to the Court's finding that there was no disadvantage caused by prejudice or stereotyping — in other words, no discrimination. ${ }^{51}$

As noted earlier, there has been a fair degree of criticism about the Supreme Court's use of comparators in its s. 15(1) analysis. ${ }^{52}$ We have gone on at some length about comparators

an essential feature of certain other individuals, and which this group takes to render unnecessary any individualized consideration of their characteristics or circumstances” (at 298) and prejudice as "a belief in the inferiority of a certain individual that leads him to be seen as unworthy of [a] benefit” (at 302). She argues that recognition of these particular wrongs does not depend on comparative analysis.

Supra note 3 at para. 185.

Ibid. at para. 189; see also ibid. at para. 201.

Ibid. at para. 195.

Ibid. at para. 194. In Tranchemontagne, supra note 9 at para. 112, the Divisional Court interprets Ermineskin as responding to the criticisms about comparator groups that Kapp merely acknowledged. They saw the Supreme Court as "moving away from the requirement to identify a specific comparator group.” If this is so, it would have been preferable for the Court to be explicit about this approach in Ermineskin.

49 Ermineskin, ibid. (Factum of the Samson Appellants at para. 280) [Samson Factum]. By failing to give attention to the claimant's choice of comparators, the Court distances itself from previous case law, where the claimant's framing of the comparator was to be the starting point for the comparator analysis: see Law, supra note 6 at para. 58; Hodge, supra note 15 at paras. 20-21; Auton, supra note 16 at para. 52.

$50 \quad$ Ermineskin, ibid. at para. 152.

51 If we are correct here then comparative analysis seems relevant to the identification of stereotyping in Ermineskin even though Moreau argues that this is not necessarily so (see Moreau, supra note 44). This is evident in the two other cases we review in this article as well, as we will discuss below (see infra notes 113, 159, and accompanying text). 
because the Court does not use them the way it has said a court should and continues to use them despite Kapp's acknowledgement of that criticism. However, we do not wish to reify this part of the s. 15(1) analysis. Although we believe that appropriate attention to comparators would have resulted in a finding of discrimination in this case, we do not assert that this will always be the case. There will be other cases where other considerations are better at bringing out the discrimination. Here, however, it seems clear that extra obligations are being imposed on Indian beneficiaries that are not being imposed on other beneficiaries, perhaps as a result of stereotypical thinking about the ability of Indians to manage their own moneys, and this should have led to a finding of discrimination.

A related problem in the Court's approach to s. 15(1) is that there is no mention of grounds in Ermineskin, whether enumerated or analogous. A grounds-based approach to s. 15(1) is one of the few constants in the jurisprudence from Andrews to Law to Kapp. Although a number of problems have been noted with the concept of grounds, grounds do provide "the necessary history and context of discrimination," 53 and focusing on why something counts as a ground is a reminder of why discrimination is a constitutional violation. ${ }^{54}$ The parties in Ermineskin characterized the grounds at issue as "race, national or ethnic origin." 55 By failing to acknowledge that these grounds were the basis of the differential treatment in Ermineskin, the Court glosses over the very "social, political and legal context" of the claim that it now says should be the focus. ${ }^{56}$

The mention of context brings us to the second step of the Kapp test, the question of whether the distinction creates a disadvantage by perpetuating prejudice or stereotyping. Ermineskin makes it clear that this question is to be answered by considering "the broader context of a distinction." 57 That is all the guidance the Court offers on how lower courts should conduct the analysis of context. This should certainly do away with the tendency towards formalism that Law's more specific four contextual factors approach had engendered. ${ }^{58}$ However, the Court is not clear about what Law's contextual factors should be replaced with. It should not be forgotten that the role of context under s. 15(1) is to illuminate substantive inequalities. Perhaps it is telling that Ermineskin does not have the strong statements of the Court's commitment to substantive equality that Kapp had. ${ }^{59}$ All the Court has to say about substantive equality in Ermineskin is that its "statement in Turpin signals the importance of addressing the broader context of a distinction in a substantive equality analysis.”60

Dianne Pothier, “Connecting Grounds of Discrimination to Real People’s Real Experiences” (2001) 13 C.J.W.L. 37 at 40.

The enumerated and analogous grounds approach was originally put forward in Andrews as a way to keep s. 15(1) and s. 1 analytically distinct, while at the same time giving content to s. 15(1): see Andrews, supra note 7 at 163-83 (rejecting the neutral approach of treating s. 15(1) as applicable to all distinctions, and the unreasonable or unfair distinctions approach of the B.C. Court of Appeal).

Samson Factum, supra note 49 at para. 279.

Turpin, supra note 33, as cited in Ermineskin, supra note 3 at para. 193.

Ermineskin, ibid. at para. 194.

For critiques of this formalism, see e.g. Beverley Baines, "Law v. Canada: Formatting Equality” (2000) 11:3 Const. Forum Const. 65; Donna Greschner, "Does Law Advance the Cause of Equality?," Case Comment, (2002) 27 Queen's L.J. 299 at 311; Emily Grabham "Law v Canada: New Directions for Equality Under the Canadian Charter?”(2002) 22 Oxford J. Legal Studies 641 at 658-60; Hester Lessard, "Mothers, Fathers, and Naming: Reflections on the Law Equality Framework and Trociuk v. British Columbia (Attorney General)" (2004) 16 C.J.W.L. 165 at 176-82.

Kapp, supra note 1 at paras. 14-16.

Supra note 3 at para. 194. 
The discussion in Ermineskin of the second part of the test for s. 15(1) is also troubling in that discrimination seems to have been reduced to a consideration of prejudice and stereotyping. ${ }^{61}$ As noted above, the Court began to focus on these particular harms of discrimination in Kapp, tracing this understanding of discrimination back to Andrews. While the Law decision was rightly criticized, one thing it did do relatively well was to set out a broader range of harms amounting to discrimination — not just prejudice and stereotyping, but also vulnerability, powerlessness, oppression, stigmatization, marginalization, devaluation, and disadvantage more broadly. ${ }^{62}$ Based on Kapp and Ermineskin the Supreme Court has made it likely that lower courts will fixate on the words "prejudice and stereotyping” as a complete statement of the harms that s. 15(1) prohibits. This is evidenced by the other two cases we will discuss later in this article.

The Court's application of the second part of the s. 15(1) test is also disconcerting. Even if discrimination is defined as prejudice and stereotyping, the Court could have found that such harms were at play in the provisions of the Indian Act precluding investment and in the Crown's refusal to transfer the funds to the bands for their own investment. The Court tries to frame the money management rules and Crown practice as matters of "Aboriginal selfdetermination and autonomy," but at the same time acknowledges that "the level of appropriate involvement and control on the part of the Crown" is relevant to how Indian moneys are regulated. ${ }^{63}$ If the broader social, political, and legal context had been considered, Crown control over Indian moneys could have been seen as part of the long history of paternalism and colonialism under the Indian Act, harms that are surely based, at least in part, on stereotyping and prejudice. ${ }^{64}$

Altogether, there is little in Ermineskin's application of the return to Andrews to make us feel hopeful about the Court's treatment of s. 15(1) and its understanding of (in)equality. ${ }^{65}$

$61 \quad$ Ibid. at paras. 188, 190, 192, 201-202.

62 Law, supra note 6 at paras. 29, 42, 44, 47, 53, as consolidated in Newfoundland (Treasury Board) $v$. N.A.P.E., 2004 SCC 66, [2004] 3 S.C.R. 381 [N.A.P.E.] (Intervener Factum of Women's Legal Education and Action Fund at para. 17), online: LEAF <http://www.leaf.ca/legal/facta/2004newfoundland.pdf\# target> [LEAF Factum]. See also Moreau, supra note 44 (arguing that in addition to stereotyping and prejudice, the wrongs of unequal treatment include perpetuation of unequal power relations and lack of access to basic goods); Denise Réaume, "Law v. Canada (Minister of Employment and Immigration)," Case Comment, (2006) 18 C.J.W.L. 143 at 168-70 (arguing that inequality includes exclusion from “dignity-constituting benefits”); Jonnette Watson Hamilton \& Dan Shea, "The Value of Equality: End, Means or Something Else?” 29 Windsor Rev. Legal Soc. Issues [forthcoming in 2010] (examining the posited relationship of equality to other values in the Supreme Court's equality jurisprudence).

$63 \quad$ Ermineskin, supra note 3 at para. 195.

64 Other harms - namely the perpetuation of unequal power relations and oppression — could also be seen as relevant in this case.

65 Another decision which leaves little hope for s. 15(1) post-Kapp is Alberta v. Hutterian Brethren of Wilson Colony, 2009 SCC 37, [2009] 2 S.C.R. 567 [Hutterian Brethren]. Because a majority of the Supreme Court finds the freedom of religion violation justified under s. 1, it goes on to consider the alternative argument that a photo requirement for drivers' licences violates s. 15(1). In a few short paragraphs the majority dismisses the s. 15(1) argument as well, finding that any distinction based on religion "arises not from any demeaning stereotype but from a neutral and rationally defensible policy choice” (at para. 108). For a critique of this case, see Jennifer Koshan \& Jonnette Watson Hamilton, “"Terrorism or Whatever': The Implications of Alberta v. Hutterian Brethren of Wilson Colony for Women's Equality and Social Justice” in Sheila McIntyre \& Sandra Rodgers, eds., The Supreme Court of Canada and the Achievement of Social Justice: Commitment, Retrenchment or Retreat, Sup. Ct. L. Rev. [forthcoming in 2010]. 


\section{THE RETURN OF LAW? MORROW V. ZHANG}

In February 2008, Justice Neil Wittmann struck down Alberta's cap on non-pecuniary damages for soft tissue injuries, finding that the cap violated the equality rights of motor vehicle accident victims and could not be justified as a reasonable limit under s. 1 of the Charter ${ }^{66}$ Law set out the governing test at the time of the trial decision and, in spite of its acknowledged problems, the application of this test seemed to lead to the conclusion that the cap was contrary to s. 15(1) rather easily.

The cap was implemented via the Minor Injury Regulation, which limits the nonpecuniary damages of minor injury motor vehicle accident victims to $\$ 4,000$ (adjusted to the cost of living index). ${ }^{67}$ Minor injuries are defined as sprains, strains, and whiplash "that [do] not result in a serious impairment." ${ }^{\text {"68 }}$ But for the cap, the claimants in Morrow would have been entitled to non-pecuniary damages in the range of $\$ 15,000$ to $\$ 20,000$. At trial, Wittmann J. found that the claimants were subject to differential treatment because the cap would not compensate their pain and suffering as fully as accident victims suffering other kinds of injury. This was seen as a distinction based on physical disability, thus meeting the first and second steps of the Law test. Further, Wittmann J. had no difficulty finding that the contextual factors supported a finding of substantive discrimination under the third step of Law. Relying on the Alberta Court of Appeal decision in Ferraiuolo Estate v. Olson, ${ }^{69}$ where limitations on damages for grief and loss of care in the Fatal Accidents Act ${ }^{70}$ were struck down under the Charter, Wittmann J. concluded that overall, "[t]he deprivation of an equal share of resources, benefits or rights on the basis of an enumerated ground, goes to the heart of human dignity,"71 and a s. 15(1) violation was made out in the circumstances.

This decision was overturned by a unanimous Alberta Court of Appeal in June 2009. Rendering the first judgment of the Court of Appeal to consider s. 15(1) since Kapp, Justice Patricia Rowbotham (with Justices Elizabeth McFadyen and Clifton O’Brien concurring) held that, when viewed in the context of the overall scheme of insurance reforms, the cap did not violate s. 15(1) of the Charter.

The Court of Appeal acknowledged the problems with the Law test by quoting the relevant paragraphs from Kapp. ${ }^{72}$ The Court then referred to Peter Hogg's Constitutional Law of Canada $^{73}$ as authority for the proposition that:

[S]ince Kapp, for a section 15 challenge to succeed, it is still necessary for a claimant to establish something in addition to disadvantage based on an enumerated or analogous ground. The additional something (discrimination) is no longer an impairment of human dignity, but rather the perpetuation of disadvantage or stereotyping. $^{74}$

Morrow v. Zhang, 2008 ABQB 98, 421 A.R. 1 [Morrow (Q.B.)].

Alta. Reg. 123/2004 [MIR].

Ibid., s. 1(h).

2004 ABCA 281, 357 A.R. 68.

R.S.A. 2000, c. F-8.

Morrow (Q.B.), supra note 66 at para. 255.

Morrow (C.A.), supra note 4 at para. 51, quoting Kapp, supra note 1 at paras. 21-24.

Peter Hogg, Constitutional Law of Canada, looseleaf, vol. 2, 5th ed. (Toronto: Thomson Reuters, 2007).

Supra note 4 at para. 52 [emphasis added], citing Hogg, ibid. at 55-31 to 55-32. 
The Court probably meant to say that "something in addition to a distinction based on an enumerated or analogous ground" is required, as disadvantage is itself a marker of discrimination. ${ }^{75}$ That aside, and noting that this approach was recently confirmed in Ermineskin, Rowbotham J.A. states as follows:

I acknowledge that in light of Kapp and Ermineskin and the academic commentary on these cases, the focus of the discrimination analysis should be directed to two concepts: (1) the perpetuation of prejudice and disadvantage to members of a group on the basis of personal characteristics identified in the enumerated and analogous grounds, and (2) stereotyping on the basis of these grounds that do not correspond to a claimant's or group's actual circumstances and characteristics. ${ }^{76}$

In spite of this acknowledgment, at first blush the Court of Appeal seems to simply apply the old Law test in its s. 15(1) analysis. After holding that the trial judge did not err in finding a distinction based on disability, the Court begins its discussion of "substantive discrimination" 77 by referencing Law (and Law alone), and then it proceeds to apply each of the four contextual factors from Law. This does not appear to be simply a review of Wittmann J.'s findings on the various stages of the Law test. The Court uses headings that mirror the four contextual factors from Law, and does not relate those factors to the notions of prejudice, disadvantage, and stereotyping that it acknowledged are now to be "the focus of the discrimination analysis."78

However, on closer examination, the Court could be said to apply a "Law-lite" approach. The Court goes through the steps from Law without a focus on human dignity, which results in the application of the Law test in a very formalistic way, rather than substantively. This is not only troubling because the Court does not do what it purports to do, but also because the use of the original Law test with a focus on human dignity could have rather easily resulted in an affirmation of the trial judge's decision. Alternatively, and perhaps more importantly, an application of the test from Kapp could also have resulted in an affirmation of the trial judge's decision had that application really focused on stereotyping.

It must be recalled that Law's four contextual factors were meant to contextualize something - that is, human dignity. ${ }^{79}$ At the same time, in Kapp the Supreme Court stated that the factors cited in Law "should not be read literally as if they were legislative dispositions, but as a way of focussing on the central concern of s. 15 identified in Andrews - combating discrimination, defined in terms of perpetuating disadvantage and stereotyping.” ${ }^{\circ 0}$ Putting Iacobucci J.’s statement from Law together with Kapp, the idea seems to be that a court could use Law's four contextual factors in order to demonstrate that the challenged legislation has the effect of perpetuating disadvantage or stereotyping. ${ }^{81}$

The misstatement appears to originate in Hogg, ibid.

Morrow (C.A.), supra note 4 at para. 53.

This is in the heading preceding ibid. at para. 86 .

Ibid. at para. 53.

Law, supra note 6 at para. 62, where Iacobucci J. noted that these are "factors which may be referred to by a s. 15(1) claimant in order to demonstrate that legislation has the effect of demeaning his or her dignity" [emphasis added].

Supra note 1 at para. 24; see also Sarah T. Kraicer, "R. v. Kapp: Aboriginal Fishing, Andrews and Affirmative Action in the Supreme Court of Canada" (2008-2009) 25 N.J.C.L. 153 at 155-56 (contending that Law's contextual factors are "relevant markers of discrimination”).

The Supreme Court did not do this in Ermineskin, supra note 3, but this may have been because the Law test was not used by the lower courts. 
There are two signs in the Court of Appeal's judgment that it was attempting to adapt the four contextual factors from Law to these reformulated ends. First, Law's first contextual factor is now referred to merely as "Pre-existing Disadvantage or Stereotype,"82 suggesting a narrower understanding of discrimination. Second, the four contextual factors from Law have become five factors in the Court's analysis of "substantive discrimination." After Law's first contextual factor, the Court of Appeal adds "Perpetuation of the Stereotype" as a separate consideration. ${ }^{83}$ This seems to acknowledge the need for more of a focus on one of the two types of discrimination recognized by Kapp and its language of "perpetuation." Alternatively, perhaps it was added because, while the Court grudgingly agreed with the trial judge that "minor injury victims ... are subjected to pre-existing stereotyping and prejudice," ${ }^{85}$ they disagreed with his assessment that the cap on general damages perpetuated this perception. However, adding "perpetuation of the stereotype" as another factor to be proven by the claimant appears to create an additional burden — something that Kapp said was to be avoided.

The balance of the Court's application of the Law test does not seem to have been adapted to meet the new approach from Kapp. For example, the Court of Appeal includes Law's third contextual factor as part of its s. 15(1) analysis despite the fact that Kapp indicated this factor "goes to whether the purpose is remedial within the meaning of s. 15(2)." ${ }^{\text {"86 }}$ It is true that the Supreme Court in Kapp did go on to add parenthetically "that the third Law factor might also be relevant to the question under s. 15(1) to whether the effect of the law or program is to perpetuate disadvantage," ${ }^{87}$ but the Court of Appeal does not use it that way. They discuss "whether the distinction was designed to improve the situation of a more disadvantaged group." ${ }^{88}$ This consideration no longer belongs in a s. 15(1) analysis according to Kapp.

Further, although the Court of Appeal is quite critical of the way that s. 1 justifications have slipped into the s. 15(1) rights violation analysis, and particularly the analysis of the second and fourth contextual factors in $\mathrm{Law}^{89}$ the Court's use of these two factors perpetuates this problem. Its analysis of the correspondence between the ground claimed and the needs, capacities, and circumstances of the claimants - Law's second contextual factor — is all about rising insurance premiums and the purpose of the legal reforms. ${ }^{90}$ There is nothing in Kapp that states that the purpose of the legislation can undermine a s. 15(1) claim (although it may be relevant to a s. 15(2) analysis), or that the focus should be on intent and not impact. Kapp's resurrection of Andrews should have reinstituted the idea that

Morrow (C.A.), supra note 4 in the heading to para. 87, and at para. 88.

Ibid. at paras. 96-103.

Kapp, supra note 1 . While Kapp uses the language of "perpetuation" in relation to prejudice and disadvantage (but not stereotyping) at para. 18, its language at paras. 23-24 suggests that "perpetuation" may modify “stereotyping” as well as “prejudice.” This is yet another aspect of the judgment where there is a lack of clarity. However, in Ermineskin, supra note 3 at para. 190, it is clear grammatically that "perpetuate" must modify both "prejudice” and "stereotyping.” A requirement for perpetuation suggests a need to prove prejudice or stereotyping that pre-existed the impugned law or program. What of claims that the impugned program itself creates the disadvantage? See our discussion of a similar requirement for "pre-existing disadvantage" in our discussion of Cunningham (C.A.), supra note 5, in Part V, below. Morrow (C.A.), supra note 4 at para 87. We characterize it as "grudging" because the best light the Court of Appeal seems to be able to put on this finding is that they "cannot say that his finding in this regard was incorrect” (at para. 92).

Kapp, supra note 1 at para. 23.

Ibid.

Morrow (C.A.), supra note 4 at para. 127.

Ibid. at paras. 134, 148.

Ibid. at paras. $107-11$. 
unconstitutional purpose or effects of a law would be sufficient to prove a s. 15(1) claim, ${ }^{91}$ but the Court of Appeal does not follow this approach.

There is another aspect of the Court's focus on legislative purpose that is problematic. The cap on non-pecuniary damages was enacted in 2004 as part of a package of insurance reforms which also included a Diagnostic and Treatment Protocols Regulation. ${ }^{92}$ The DTPR provides pre-authorized payments for treatment for accident victims without the need to seek the insurer's approval..$^{93}$ At trial, Wittmann J. declined to consider the cap in light of the other insurance reforms (including the DTPR), as this might "[shield it] from effective review." He thereby distanced himself from Law's tendency to internally limit equality rights based on the consideration of government objectives. The critique of Law in Kapp arguably opened the door for the Court of Appeal to support this aspect of Wittmann J.'s decision. Instead, the Court of Appeal holds that Wittmann J. erred when he failed to give sufficient weight to the other insurance reforms. In particular, the Court finds that a fair amount of weight should be given to the treatment options provided by the DTPR, which "promote and assist treatment" and provide for "an individualized assessment of a claimant [that] cannot normally be characterized as perpetuating a stereotype." ${ }^{95}$ The $D T P R$, however, provides relief for accident victims' costs of care. This is a form of pecuniary damages, unlike the nonpecuniary damages for pain and suffering that are capped at $\$ 4,000$. How can legislation that deals with a different head of damages that claimants are entitled to in any event be relevant to whether the cap on general damages is discriminatory ${ }^{96}$

The Court also finds the DTPR to be significant on the basis that it provides preauthorized payment for treatment that the plaintiff would previously pay for up front and seek reimbursement for from the insurer. There was evidence at trial that the DTPR had a positive impact: "more injured claimants were receiving health services in the first 12 weeks following their injuries, the costs per treatment had decreased, and fewer claims were unresolved after 26 weeks than had been the situation prior to the reforms." 97 If the argument is that this somehow reduces pain and suffering and the need for general damages, this point is not made explicit by the Court.

Given all the difficulties with its application of Law, without Law's human dignity focus, it is worthwhile to ask what difference it might have made had the Court of Appeal either used the Law test as it was formulated or, more importantly, had they used the approach set out in Kapp.

Although the focus on human dignity in the Law test is subjective and difficult to apply, the consideration in Morrow of the human dignity of the claimants does make clear the discriminatory impact of the MIR. Alberta insurers and the public were concerned about the

Andrews, supra note 7 at 182-84.

Alta. Reg. 122/2004 [DTPR].

Also noted by the Court of Appeal are several other regulations which set and cap auto insurance premium levels, and govern auto insurance coverage and disputes about coverage more broadly (Morrow (C.A.), supra note 4 at paras. 17-23).

Morrow (Q.B.), supra note 66 at para. 163.

Morrow (C.A.), supra note 4 at para. 98.

The Court of Appeal actually acknowledges that all other accident victims also get individualized damages for their out of pocket expenses for the costs of care: see ibid. at para. 132.

Ibid. at para. 23. 
rising cost of motor vehicle insurance premiums. ${ }^{98}$ Increases in bodily injury costs on automobile insurance premiums were blamed on increasing awards for non-pecuniary damages, a significant proportion of which appeared to be minor soft tissue injuries. ${ }^{99}$ The insurance law reforms, particularly the $M I R$, reduced automobile insurance premiums by singling out those who suffered from certain types of minor injuries — soft tissue injuries or whiplash - and capping their damages for pain and suffering at $\$ 4,000$. Consider the alternatives the government could have implemented: everyone suffering a minor injury in a motor vehicle accident could have had their non-pecuniary damages capped, or more broadly, everyone suffering an injury in a motor vehicle accident could have had their nonpecuniary damages capped. ${ }^{100}$ Choosing either of these alternatives would have also reduced insurance premiums for all drivers. By singling out only those suffering minor soft tissue injuries in motor vehicle accidents, the government made this one group of people pay for reduced insurance premiums for all drivers. The message sent to those suffering minor soft tissue injuries in motor vehicle accidents is that they are less worthy of concern and respect when their government makes them, and them alone, bear the cost of reducing insurance premiums. ${ }^{101}$ This is the very definition of a violation of human dignity. ${ }^{102}$

What might have been the result had the Kapp approach — the approach mandated by the Supreme Court of Canada - been used? Once it is found that the law creates a distinction based on an enumerated or analogous ground, the Kapp approach asks whether the distinction creates "a disadvantage by perpetuating prejudice or stereotyping?"103 At trial, Wittmann J. found that those suffering minor soft tissue injuries in motor vehicle accidents are stereotyped as "malingerers and fraudsters or that their pain is not real." ${ }^{104}$ Unlike other minor injuries caused by motor vehicle accidents which can be seen on an x-ray or other image, those suffering minor soft tissue injuries suffered from "invisible disabilit[ies]."105 Thus, the trial judge concluded that "discrimination results from the apparent message that Minor Injury victims' pain is worth less or is not 'real'.,"106

The Court of Appeal did not disagree enough with the trial judge that soft tissue injury claimants are subjected to stereotyping to overturn him on this finding of fact. However, they do not discuss the stereotyping in much detail, merely noting that the trial judge found that these claimants "are often viewed as malingerers who exaggerate their injuries or the effects of those injuries in an effort to gain financially." 107 Because the Court of Appeal holds that a different regulation — the DTPR — recognizes that these soft tissue injuries are "real," the impugned MIR is seen as "the antithesis of the perpetuation of the [stereotypical] soft-tissue victim who fakes or malingers his or her injury."108 In summary, the Court of Appeal seems to be saying that the stereotype is that the claimants are faking their injuries, but a regulation related to the challenged legislation acknowledges their injuries are real and, therefore, the

$98 \quad$ Ibid. at para. 1.

See e.g. Hartling, supra note 34 (upholding the constitutionality of caps on all types of minor injuries). For a similar case of singling out a particular group in order to save money, see N.A.P.E., supra note 62. Law, supra note 6 at para. 51.

Kapp, supra note 1 at para. 17.

Morrow (Q.B.), supra note 66 at para. 219. See also para. 205.

Ibid. at para. 209.

Ibid. at para. 255.

Morrow (C.A.), supra note 4 at para. 87.

Ibid. at para. 102. 
legislation not only does not perpetuate the stereotype, but it fights against it, and cannot be discriminatory.

Further, in their consideration of Law's fourth contextual factor, the Court of Appeal finds that "the nature of the interest affected here is not of 'fundamental' societal or constitutional importance." ${ }^{109}$ However, the Court does not consider whether the stereotyping suffered by those with soft tissue injuries might be at work in concluding that the nature of the interest affected by the cap was just not that important. Law's fourth contextual factor recognizes that more severe and localized consequences of distinctions drawn by law are more likely to be discriminatory. ${ }^{110}$ The consequences of saying that only those suffering minor soft tissue injuries in motor vehicle accidents will have their non-pecuniary damages capped are certainly localized. On what basis does the Court of Appeal hold that the consequences are not of fundamental societal or constitutional importance?

First, the Court says that this is not a case where the claimants were deprived of all types of compensation; they still could get damages for loss of income, cost of care, and other pecuniary damages. With full costs of care covered, it is apparently alright to "moderate" non-pecuniary damages, which are the law's mechanism for acknowledging the injured person's lost ability to enjoy activities important to them, such as lifting a child. ${ }^{111}$ The Court holds that the trial judge "erred in concluding that damages for pain and suffering are of such fundamental societal significance that to interfere with them [is] indicative of discrimination." "112 Why it is acceptable to cap damages for some people who can no longer lift their children, but not others, is not discussed. The use of one or more comparator groups here might have been helpful, as it was for the trial judge when he compared soft tissue injury victims to other motor vehicle accident victims. ${ }^{113}$

The second reason proffered is that there is a constitutionally valid cap on all nonpecuniary damages and because partial caps on damages in other provinces have been found constitutional. For the latter point, the Court relied upon Hernandez ${ }^{114}$ and Hartling. ${ }^{115}$ However, the cap challenged in Hernandez was one that precluded all claims for all types of damages (pecuniary and non-pecuniary) where the nature of the injuries were not serious enough to pass the threshold, and in Hartling the statutory cap applied to all minor injuries and was not restricted solely to soft tissue injuries. The fact that some caps on some types of damages have been found constitutional should not preclude the finding that a cap can raise an issue of fundamental societal or constitutional importance, especially where a group identified by s. 15 protected grounds is singled out.

Had the Court of Appeal taken Kapp's focus on stereotyping more seriously, the result might have been different. ${ }^{116}$ Not only is there a stereotype at work that these injuries are not 
"real" and the person claiming to suffer them is therefore faking, but faking and malingering also go towards the exaggeration of real injuries. The latter is the sort of stereotype that allows people to trivialize soft tissue injuries and to minimize their societal and constitutional importance.

Both the stereotype that soft tissue injuries are "not real" and that they are "exaggerated" can be seen in the comments of MLA Gary Masyk during the legislative debate concerning reforms to the Insurance Act:

\begin{abstract}
Mr. Speaker, it's noted at some point that when somebody gets in an accident, they open the glove box and there is already an inflatable collar. We have to discourage these things. This lawsuit based system for compensating auto injuries allows claimants to seek payment for uneconomic damages such as pain and suffering. So the rule of thumb is for lawyers and the claimant to calculate these losses at two or three times the claimant's economic losses. Economic losses are things like lost wages and medical expenses. Since pain and suffering awards are measured as a multiple of medical and wage losses, there's a powerful incentive to inflate one's claim of economic damages and pursue legal action. This should give all members a better idea of why insurance premiums have been going through the roof of late. ${ }^{117}$
\end{abstract}

The first sentence relies on the faking stereotype, and the second last sentence relies on the exaggeration stereotype. Might the Court of Appeal itself have applied such stereotypes in denying that damages for pain and suffering are not of sufficiently fundamental societal or constitutional significance that they cannot be capped for one particular, easily singled out group of persons injured in motor vehicle accidents? ${ }^{118}$

The Court's failure to draw a connection between Law's second and fourth contextual factors exemplifies a common criticism of that case. Law's contextual factors were often applied in isolation rather than looking holistically at the question of discrimination. ${ }^{119}$ The return to a broader examination of context in Ermineskin has the potential to combat the tendency to treat discrimination as a checklist, but we do not see that potential being fulfilled here.

It therefore seems that the claimants in this case could have won under the Law test (as they did in the Court of Queen's Bench) and they could have won under the approach set out in Kapp. However, they could not win under a "Law-lite" test that uses context without human dignity and imports several factors normally included in a s. 1 analysis into s. 15(1).

\title{
V. THE EVOLUTION OF LAW? \\ Cunningham V. Alberta (ABoriginal AfFairs AND NORTHERN DEVELOPMENT)
}

Only a few weeks after the decision in Morrow was released, a differently constituted Alberta Court of Appeal panel decided another s. 15 case, and the analysis and outcome of the two cases are quite different. While we have some concerns with the Court's decision in 2003) at 832. 
Cunningham, we argue that it is a much better example of how s. 15 of the Charter should be applied post-Kapp than is Morrow. Cunningham is also interesting as it applies s. 15(2) of the Charter and the Supreme Court's new approach to affirmative action under Kapp.

Cunningham deals with a claim by a number of individuals who were removed from the membership list of the Peavine Métis Settlement in 2001 by the Registrar of Métis Settlements at the request of a former Peavine Métis Council. Under s. 90 of the Métis Settlements Act, ${ }^{120}$ a Métis settlement member who voluntarily registered as an "Indian" under the Indian Act after 1 November 1990 must be removed from the Métis settlement membership list by the Registrar when requested by the settlement council. The Registrar refused to reinstate these individuals on an application by a subsequently elected Peavine Métis Council because s. 75 of the MSA prohibits an adult Métis person who holds Indian status from obtaining membership in a Métis settlement. The individuals in question initiated a Charter action for a declaration that the relevant sections of the MSA violated their rights under ss. 2(d), 7, and 15 of the Charter, and for an order requiring the Registrar to reinstate them to the Peavine membership list.

At trial, Justice Donna Shelley of the Alberta Court of Queen's Bench found that there was no violation of equality rights under s. 15(1) of the Charter, applying the then-governing test from Law. ${ }^{121}$ Justice Shelley found that, as compared to Métis individuals who had not registered as Indians, the claimants were differentially treated because they lost the benefits of settlement membership, including the ability to participate in the Métis community, the right to vote in Peavine Council elections, and the right to reside on or occupy Métis land. This differential treatment was said to be based on the analogous ground of registration as an Indian under the Indian Act. ${ }^{122}$ Although the first two steps of the Law test were met, Shelley J. went on to find that there was no discrimination under the third step of the Law test. She found that the claimants were not subject to "any stereotyping or unique disadvantage," 123 and that the legislation had an ameliorative purpose that was "supported rather than undermined by the impugned provisions." ${ }^{124}$ Finally, because the applicants had voluntarily registered as Indians, their loss of Métis status and associated rights were said to be matters of personal choice. ${ }^{125}$ Overall, the application of the Law test was seen to mandate the finding that the MSA "[does] not affect the human dignity of the individual Applicants and, therefore, [is] not discriminatory."

The claimants appealed this decision to the Court of Appeal. Justice Keith Ritter, with Justices Peter Costigan and Elizabeth McFadyen concurring, begins the s. 15 analysis by referencing the Kapp decision, and interprets the case to mean that "if the state can meet the

R.S.A. 2000, c. M-14 [MSA].

Cunningham v. Alberta (Minister of Aboriginal Affairs and Northern Development, 2007 ABQB 517, 424 A.R. 271 [Cunningham (Q.B.)]. The applicants' claims based on freedom of association (s. 2(d) of the Charter) and liberty (s. 7 of the Charter) were also rejected.

122

Ibid. at para. 167, citing McIvor v. Canada (Registrar of Indian and Northern Affairs), 2007 BCSC 827, [2007] 3 C.N.L.R. 72 [McIvor]. Justice Shelley noted at para. 192 that this ground "is closely akin to the concepts of nationality and citizenship.” McIvor was affirmed in part on appeal: see McIvor v. Canada (Registrar of Indian and Northern Affairs), 2009 BCCA 153, [2009] 2 C.N.L.R. 236, leave to appeal to S.C.C. refused, 33201 (5 November 2009). 
requirements of s. 15(2), then a s. 15(1) claim will fail." ${ }^{\text {2127 }}$ Accordingly, the Court decides that it will consider s. $15(2)$ before s. $15(1) .{ }^{128}$

This is not quite right. The Supreme Court held in Kapp that all s. 15 analyses should begin with a consideration of whether there has been differential treatment based on a protected ground, the first step towards proving a claim under s. 15(1). If that step is met, a court should then turn its focus to s. 15(2) if the government has argued that the impugned law or government program has an ameliorative purpose that targets a disadvantaged group. If the government can meet its burden under s. 15(2), the s. 15(1) claim will fail. If not, the burden returns to the claimant to prove that there has been discrimination contrary to the second step of the s. 15(1) analysis. ${ }^{129}$

While it may seem overly formalistic to insist that courts sequentially follow the Supreme Court's stages of analysis from Kapp, the Court of Appeal's failure to proceed through these steps in the right order causes confusion in Cunningham. Under its s. 15(2) analysis, the Court finds as follows:

The chambers judge identified the appellants as being denied the benefits of settlement membership on the basis of their registration as Indians under the Indian Act, and correctly found that to be a personal characteristic analogous to an enumerated ground.... Because the impugned provisions target the appellants, and those similarly situated, the second part of the s. 15(2) test is met. ${ }^{130}$

In spite of its earlier statement that it would consider s. 15(2) first, the Court effectively looks at the first step of s. 15(1) in this passage and supports the trial judge's decision that there was differential treatment — the denial of the benefit of settlement membership — on the basis of a protected ground, status as an Indian. This is positive, as it is difficult to see how the s. 15(2) analysis could proceed without an initial determination of the nature of the discrimination being claimed under s. 15(1). However, to go on to say that because there is differential treatment on a protected ground the impugned provision targets a disadvantaged group for the purposes of s. 15(2) is surely incorrect for two related reasons. First, it is the MSA which is ameliorative, not the provision in the statute which was challenged. Second, the whole gist of s. 15(2) is to protect programs that are targeted at disadvantaged groups other than the claimants. In Kapp, for example, the fishing program at issue gave some west coast Aboriginal fishers a 24-hour lead over fishers who were not included in the program. The excluded fishers claimed discrimination, and the Supreme Court held that even though there was differential treatment against this group based on a protected ground, the program was designed to ameliorate the disadvantage of another group (that is, the Aboriginal fishers) and could not, therefore, be seen as discriminatory. In Cunningham, in addressing whether the law targeted a disadvantaged group, the Court should first have looked at who the ameliorative program was designed to benefit, not who was being disadvantaged by the exclusion from those benefits. 
If a disadvantaged group is wrongly excluded from an ameliorative program, they should be able to successfully mount a discrimination claim, as the targeted group may have been too narrowly framed by the government. This was a key issue left open by Kapp, ${ }^{131}$ and the Court of Appeal does go on to consider the question of underinclusiveness in Cunningham. But the starting point for s. 15(2) should be the determination of which disadvantaged group(s) the law or program was targeted at, and not on who it excludes. ${ }^{132}$

In Cunningham, the Court of Appeal quickly recovers from its misstep under s. 15(2) by considering whether the challenged law rationally advances its intended ameliorative purpose. The first question in the s. 15(2) analysis formulated in Kapp is whether or not the program has an ameliorative or remedial purpose. ${ }^{133}$ It is not just the government's statement of its intentions which count in determining purpose. The Supreme Court made it clear that courts may consider "whether the legislature chose means rationally related to that ameliorative purpose, in the sense that it appears at least plausible that the program may indeed advance the stated goal of combatting disadvantage.”134 When the Court of Appeal considers the relation of the means to the purpose in Cunningham, the Court correctly shifts to an assessment of the MSA's overall ameliorative purpose, which it finds to be "to aid the enhancement and preservation of Métis culture and identity, and enable a degree of selfgovernance ... [as well as] to preserve a Métis land base.”135 The problem for the government is that the exclusion of the claimants is seen to detract from, rather than advance, this purpose. The Court thus concludes that their exclusion is arbitrary rather than rationally connected to the purpose of the MSA as it "potentially [excludes] Métis settlement members like the appellants, who, for a long time, have identified with and lived the Métis culture.”136 Note how the Court of Appeal in that passage considered the effect of the impugned provision on the claimants in answering the question of whether the overall law had an ameliorative purpose.

Kapp, supra note 1 at para. 41.

Two members of the Supreme Court of Canada make a similar error in A.C. v. Manitoba (Director of Child and Family Services), 2009 SCC 30 [2009] 2 S.C.R. 181 [A.C.], released the same day as Cunningham (C.A.). In that case, McLachlin C.J.C. and Rothstein J. find that legislation which limits decisions that minors can make about their medical treatment is ameliorative, and therefore not discriminatory (at para. 152). This finding is said to be based on the law's protection of minors as a vulnerable group, but this is the very group to which the claimant A.C. belonged. If ameliorative purpose can be used this way, it means that laws will not be seen as discriminatory if they are characterized as having been imposed for the claimant group's own good. This interpretation is contrary to Kapp, where the Court stated that "laws designed to restrict or punish behaviour" are not ameliorative (Kapp, ibid. at para. 54).

Kapp, ibid. at para. 41.

Ibid. at para. 48 .

Supra note 5 at para. 24 .

Ibid. at para. 28. Section 15(2) was not raised by the government as a bar to the s. 15(1) claim of soft tissue injury victims in Morrow. However, recall the Court of Appeal's focus on the legislative purpose of the insurance reforms in that case, albeit under s. 15(1). If the logic of Cunningham had been followed in Morrow, the Court should have found no rational connection between the purpose (reduced premiums) and the singling out of a particular group to achieve that purpose. In other words, the cap was arbitrary just as the exclusion of "Indians" from the Métis settlement list was arbitrary. Although Law's second contextual factor allows for an analysis of arbitrariness in examining the connection between the law and the claimants' actual needs and circumstances. Law's importation of a rational connection analysis into s. 15(1) has been criticized: see e.g. Sheilah Martin, "Balancing Individual Rights to Equality and Social Goals" (2001) 80 Can. Bar Rev. 299. This provides another example of how the proper application of Law by the Court of Appeal in Morrow would have resulted in a finding of discrimination. 
Importantly, the Court does not accept the government's argument that because the overall purpose of the MSA is ameliorative, this should bar the s. 15 claim. The Court draws an analogy to the case of Vriend, ${ }^{137}$ where the exclusion of sexual orientation as a protected ground under Alberta's human rights legislation was found to be discriminatory. Surely, the Court suggests, we would not say that Vriend is now bad law in light of Kapp simply because a government could prove that human rights legislation has an overall ameliorative purpose. ${ }^{138}$ We would still find the exclusion of a particular group that required human rights protection - that is, of another disadvantaged group - to be discriminatory. In order to avoid overturning years of s. 15 case law dealing with the discriminatory exclusion of particular groups from benefit conferring legislation, Kapp must leave space to find that this sort of exclusion violates s. 15(1) in spite of s. 15(2). In our opinion, the Court of Appeal got this aspect of its judgment right.

It may be, however, that there is a better way to analyze challenges of underinclusion to ameliorative laws, programs, or activities. ${ }^{139}$ While purportedly analyzing the purpose of the overall legislation, the Court of Appeal had to look to the effect of the impugned provision within that legislation to find that s. 15(2) was inapplicable. In Kapp, the Supreme Court explicitly considered the issue of whether courts should look to the purpose or to the effect of legislation under s. 15(2), and was adamant that it was the purpose which was the paramount consideration. ${ }^{140}$ Under the Kapp approach, the principal difference between ss. 15(1) and 15(2) is whether the court evaluates effects. However, when the challenge is an allegation of underinclusiveness, as in Cunningham, the real issue is the basis of the exclusion of the claimants from the ameliorative program and the effects of that exclusion, rather than the overall ameliorative purpose of the program. When underinclusion is the real issue the court focuses on purpose rather than effects. This results in the risk that the purpose of the ameliorative law or program and the purpose of the claimants' exclusion from that law or program will become confused or conflated. For example, when underinclusion is the issue as in Cunningham, the relevant purpose is not, for example, the purpose for including Métis within the MSA; the relevant purpose must be the purpose of excluding the claimants from the MSA. Further, it is not enough to look only to the purpose of the denial of the

Vriend v. Alberta, [1998] 1 S.C.R. 493 [Vriend].

Cunningham (C.A.), supra note 5 at para. 23. There is a possible issue as to whether or not human rights legislation, such as that considered in Vriend, qualifies as an ameliorative law within the meaning of $\mathrm{s}$. 15(2). The heading for that subsection is "Affirmative action programs" and this might be narrowly understood as including only those programs which give a priority to disadvantaged individuals or groups. The question was not discussed in Kapp, perhaps because the 24-hour exclusive fishery at issue in that case was a program which gave priority access to the salmon fishery to three First Nations. The Supreme Court did not define "ameliorative" although it stated that "broad societal legislation, such as social assistance programs" are not within the scope of s. 15(2) (Kapp, supra note 1 at para. 55). Is provincial human rights legislation broad societal legislation? Or is it legislation which targets the conditions of specific and identifiable disadvantaged groups and thus falls within s. 15(2), even if it does not give a priority to those groups? If one looks to the purpose of legislation, which prohibits discrimination on the basis of enumerated grounds in the provision of goods and services, employment, and accommodation, surely it is legislation which targets groups that have historically been denied goods and services, employment, and accommodation and thus it is ameliorative.

We would like to thank Dianne Pothier for these points about purpose and effect, made in her oral argument in Jean v. Canada (Indian and Northern Affairs and Northern Development), 2009 FCA 377, [2009] F.C.T. No. 1656 (oral argument, appellant) [Jean] (challenging the Indian and Northern Affairs Canada Elementary/Secondary Education Program on the basis that it makes a discriminatory distinction between students who live on reserve or Crown land and student members of landless bands); see also Jean (Intervener factum of the Women's Legal Education and Action Fund), online: LEAF < http://www. leaf.ca/legal/facta/2009-micmac1.pdf\#target>.

Kapp, supra note 1 at paras. 43-52. 
benefits of the targeted program. To achieve substantive equality, the court must also look to the effects of the exclusion under s. 15(1), as the Court of Appeal actually did in Cunningham. Claims of underinclusion must receive the full s. 15(1) analysis in order to ensure that "[g]overnments ... are not permitted to protect discriminatory programs on colourable pretexts." ${ }^{141}$ Arguments of a rational connection under s. 15(2) should not preclude a full s. 15(1) analysis.

In Cunningham, the Court of Appeal begins its discussion of s. 15(1) by noting that the only issue of contention (having disposed of the s. 15(2) argument) is whether the differential treatment on a protected ground is discriminatory. ${ }^{142}$ The Court describes how the question of discrimination would have been analyzed under Law, with the law's impact on human dignity assessed via four contextual factors. It then states that Kapp "clarified" Law, and that "a proper analysis of whether differential treatment is discriminatory involves determining whether the distinction drawn creates a disadvantage by perpetuating prejudice or stereotyping." ${ }^{143}$ Put another way, “[d]iscrimination can be found through two avenues: decisions or laws that perpetuate the prejudice or disadvantage of a claimant, and decisions or laws that are based on inaccurate stereotypes." 144

As we have argued, this is too narrow a test of discrimination, and a broader range of harms — including vulnerability, powerlessness, oppression, stigmatization, marginalization, devaluation, and denial of important benefits - should be recognized. However, the Court in Cunningham does articulate the test properly according to the Supreme Court's recent pronouncements on s. 15 in Kapp and Ermineskin.

The Court then turns to the application of the test. Looking first at the perpetuation of prejudice or disadvantage, and following Kapp, the Court notes that three of the contextual factors from Law continue to be relevant to this analysis: the nature and scope of the interest affected (Law's fourth factor), whether the appellants suffered pre-existing disadvantage, stereotyping, prejudice, or vulnerability (Law's first factor), and whether the law has an ameliorative purpose or effect ( $L a w$ 's third factor). ${ }^{145}$ Having already dealt with ameliorative purpose under s. 15(2), the Court focuses on the other two factors.

In terms of the nature and scope of the interest affected, the Court agrees with the trial judge's holding that the deprivation of settlement membership has severe consequences for the claimants and others. However, the Court disagrees with her finding that because the claimants chose to become registered as Indians, this somehow mitigated the seriousness of the consequences. ${ }^{146}$ This is an important finding. Choice has been used to the detriment of many equality rights claimants under $L a w^{147}$ and may rely on certain preconceptions about 
individual freedom and autonomy that do not comport with reality. ${ }^{148}$ Particularly in the context of Aboriginal equality rights claimants, decisions about, for example, whether to reside on or off reserve, or whether to acquire Indian status, are made in the context of a complex history of colonialism and discrimination that cannot be easily equated to a simple matter of "choice." 149

It is difficult to say that the Court of Appeal's dismissal of choice-based reasoning in Cunningham is a direct result of its application of a revised test for discrimination. But it may be that the retreat from human dignity as the focus of s. 15(1) does play a part in minimizing the role of choice in the discrimination analysis. ${ }^{150}$ Law's statement of the purpose of s. 15(1) indicated that human dignity went hand in hand with "freedom" and "the realization of personal autonomy and self-determination." "151 Freedom, personal autonomy, and selfdetermination are not the same as "choice," but those who understand freedom as negative liberty often conflate these ideas, ${ }^{152}$ so that discrimination is not seen when individuals are prevented from exercising choice. ${ }^{153}$ And while human dignity may have disappeared following Kapp, Ermineskin indicates that autonomy and self-determination are still alive and well as s. 15(1) considerations. ${ }^{154}$

Moving on to the discussion of pre-existing disadvantage, stereotyping, prejudice, or vulnerability, the Court states that proof of a "unique pre-existing disadvantage” is required to support a finding of discrimination, relying upon Martin. ${ }^{155}$ Martin does not, however, require "unique pre-existing disadvantage," rather, it held that "while a finding of relative disadvantage may in certain cases be helpful to the claimant, the absence of relative disadvantage should ... be seen as neutral when, as is the case here, the claimants belong to

See Diana Majury, "Women are Themselves to Blame: Choice as a Justification for Unequal Treatment” in Faraday, Denike \& Stephenson, supra note 9 at 209; Sonia Lawrence, "Choice, Equality and Tales of Racial Discrimination: Reading the Supreme Court on Section 15," in McIntyre \& Rodgers, supra note 14, 115; see also James T. McClary, "A Different View of Nova Scotia (Attorney-General) v. Walsh" (2005) 22 Can. J. Fam. L. 43; Onofrio Ferlisi, "Recognizing a Fundamental Change: A Comment on Walsh, the Charter, and the Definition of Spouse," Case Comment, (2001) 18 Can. J. Fam. L. 159 at $176-79$.

See Corbiere v. Canada (Minister of Indian and Northern Affairs), [1999] 2 S.C.R. 203 at paras. 62, 84. See Majury, supra note 148 at 219-20.

Supra note 6 at para. 53. See also paras. 48, 51.

The distinction between negative and positive liberty or freedom is a basic one, classically set out by Isaiah Berlin in his essay "Two Concepts of Liberty" in Four Essays on Liberty (New York: Oxford University Press, 1971) 118. According to Berlin, negative liberty is the absence of external constraints to the exercise of choice. Freedom is external and objective and not the subjective expression of desire, i.e., choice. However, the choosing subject of liberty and subjective desire are not seen as contingent on social circumstances and thus choice may be unproblematically allied to freedom. For a review of these ideas and an extended critique of the classical understanding of freedom, see Nancy J. Hirschmann, The Subject of Liberty: Towards a Feminist Theory of Freedom (Princeton: Princeton University Press, 2003) at 1-34. Autonomy or self-determination is usually distinguished from freedom or liberty, but the traditional conception of autonomy as self-rule overlaps with the negative conception of freedom, sharing its individualism and defining itself as absolute freedom from the influence of others: see Cass R. Sunstein, "Preferences and Politics" (1991) 20 Philosophy \& Public Affairs 3 at 11 . However, it also overlaps with the idea of positive liberty, which traditionally concerns itself with providing the conditions necessary to take advantage of negative liberties: see e.g. Joseph Raz, The Morality of Freedom (Oxford: Clarendon Press, 1986). that claimants are usually seen as being prevented from making choices due to stereotyping (supra note 148 at 117).

$154 \quad$ Supra note 3 at para. 195.

155 Nova Scotia (Workers' Compensation Board) v. Martin, 2003 SCC 54, [2003] 2 S.C.R. 504 at paras. 86-88 [Martin], as cited in Cunningham (C.A.), supra note 5 at para. 41 [emphasis in original]. 


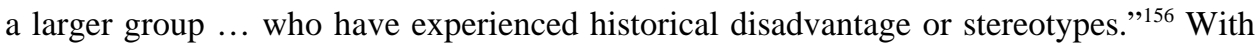
respect, there is a distinction between "relative" disadvantage and "unique" disadvantage, the latter being much more difficult for the claimant to prove.

Even so, the Court finds that the claimants' loss of settlement benefits is a "unique [preexisting] disadvantage." 157 It is difficult, however, to see the disadvantage described here as "pre-existing," as it flows from the impugned provisions themselves. Is the disadvantage "unique," or more appropriately, was there "relative disadvantage" as contemplated by Martin? One way to look at Cunningham would be to view it as being analogous to Martin — that is, the claimants belong to a larger group (the Métis) that has experienced historical disadvantage or stereotyping, so the lack of relative disadvantage with other Métis persons would be seen as neutral. Alternatively, there was evidence before the Court upon which a finding of relative pre-existing disadvantage could have been made. ${ }^{158}$ However, there is case law and literature suggesting that thinking in terms of such "hierarchies of disadvantage" should be avoided under s. 15(1), and we agree with that position. As noted in Lovelace, “"pitting one disadvantaged group against another'... is inconsistent with the fullness of the substantive equality analysis.” 159

The Court's mistaken reliance on unique disadvantage is not critical to the outcome in any event. In addition to disadvantage, the Court found that there was stereotyping at play in the case based on the fact that the claimants, because they are status Indians, "are consequently seen by some as being 'less Métis." "160 The MSA is seen to perpetuate this stereotype "by terminating the appellants' settlement memberships, encouraging a wrongful presumption that because the appellants registered as Indians, they are not interested in participating in their community and identifying as Métis."161 The Court also links stereotyping to Law's second contextual factor. If the law is based on stereotypical assumptions about the claimants' needs rather than on their actual situation, this will support a finding of discrimination. ${ }^{162}$ Here, the Court finds that "the impugned provisions fail to account for the appellants' needs and circumstances in terms of belonging to a settlement and self-

Martin, ibid. at para. 88 [emphasis added]. In Martin it was the government who argued that the claimants had to establish not only that they were affected by the general pre-existing disadvantage or stereotypes applicable to all injured workers, but also that they had been subject to greater historical disadvantage or stereotyping. The Supreme Court rejected this argument. Its point on relative disadvantage will often be the case where the claim is one of underinclusion. In such cases, relative disadvantage will not exist because the claim is "we are the same" (or in the same need of a benefit) as the group receiving the benefit (although in some cases the excluded claimant group may argue that it is worse off).

157 Cunningham (C.A.), supra note 5 at para. 41, citing Lovelace, supra note 27 at para. 70.

158 One of the claimants, Ralph David Cunningham, deposed that his mother lost her Indian status when she married his Métis father, but then regained it in 1985, entitling Cunningham to regain status as well: see Cunningham (C.A.), ibid. at para. 5. This story, said to be "typical" of the claimants, points to a common history faced by the descendents of women who lost their Indian status when they "married out."; see also McIvor, supra note 122, dealing with a challenge to An Act to amend the Indian Act, S.C. 1985, c. $27 \mathrm{~s} .4$, more commonly known as Bill C-31. It supports a finding of relative, and perhaps even unique pre-existing disadvantage, as only persons in this category would have faced the myriad complexities associated with deciding whether to seek reinstatement as Indians (of which the consequences of the MSA, supra note 120 , are only one aspect). Lovelace, supra note 27 at para. 59. See also Moreau, supra note 44 at 303, 306, 312. a comparative element. Here we see the claimants being stereotyped as "less Métis" than those who have not registered as Indians. Ibid.

Ibid. at para. 46. 
identifying as Métis." 163 This is so even though the claimants "chose” to register as Indians and thus became eligible for certain benefits under the Indian Act that were not available to them under the MSA (such as health benefits).

Cunningham provides a nice contrast with both Morrow and Ermineskin in its treatment of stereotyping. As we have argued, the Court of Appeal failed to grapple with the implications of singling out a particular category of accident victims for disadvantageous treatment in Morrow, and based its decision on the fact that they would receive other benefits under the DTPR. Similarly, in Ermineskin the Supreme Court failed to interrogate the deeper implications of a separate scheme for Indian beneficiaries that prohibited Crown investment and required proof of a financial management plan before the bands' royalties could be transferred. In contrast, the singling out of Métis persons with Indian status was seen as stereotypical in Cunningham, and the fact that the claimants were eligible for benefits under the Indian Act did not detract from the findings of stereotyping and disadvantage.

There are places in Cunningham where, as in Morrow, the Court of Appeal returns to the language and structure of the Law test. For example, the Court states that "the underlying question [of discrimination] always relates to a claimant's human dignity," and it reverts to the idea of a three step test for s. 15(1) ${ }^{164}$ However, the question of two steps or three steps is not significant (as opposed to the content of those steps), and the Court does not use human dignity in the problematic ways identified in Kapp. Overall, the Court's analysis in Cunningham, including its use of Law's contextual factors as mapped to stereotyping and prejudice, seems to be in keeping with Kapp's new direction. More importantly, it is in keeping with the purpose of s. 15 equality rights, which is "the promotion of a society in which all are secure in the knowledge that they are recognized at law as human beings equally deserving of concern, respect and consideration.”165

Cunningham is also notable as the only case in this review to get to s. 1 of the Charter. As the Court of Appeal notes in Morrow, ${ }^{166}$ this is a relatively rare occurrence since Law was decided - and this is no surprise given the importation of much s. 1 analysis into s. 15(1) in Law. Subsequent to Kapp, it will also be rare for cases to get to s. 1 if courts accept governments' s. 15(2) arguments as, by definition, there will be no finding of discrimination in such cases. However, where a government's ameliorative purpose argument fails under s. 15(2), this might mean the death knell for its s. 1 argument.

In Cunningham the Court of Appeal holds that the government could not justify the equality rights breach under s. $1{ }^{167}$ In spite of being permitted to introduce fresh evidence on appeal, the government failed to prove that the purported objectives of the MSA were the specific objectives it had in mind when it passed the legislation. ${ }^{168}$ Further, the Court holds

Ibid. at para. 48 .

Ibid. at para. 50. See also para. 52.

Andrews, supra note 7 at 171.

Morrow (C.A.), supra note 4 at 148.

Cunningham (C.A.), supra note 5 at paras. 52-58 (the Court declined to consider the alleged violations of ss. 2(d) and 7 of the Charter after finding the s. 15 breach).

Ibid. at paras. 62-64. The government applied to introduce new evidence to support the ameliorative purpose of the relevant legislation in light of the newly released Kapp decision. Justice Watson held that the appeal panel should decide whether the Crown was permitted to introduce new evidence and raise new arguments based on that evidence, and to decide if any harm or unfairness would result from the 
that the objectives, even if pressing and substantial, were not achieved via rational or minimally impairing means. ${ }^{169}$ This finding is directly related to the government's failure under s. 15(2). Because a particular group was arbitrarily excluded from retaining Métis status, the legislation could not be seen as a rational means of pursuing the government's ameliorative objectives even if it had been able to prove the latter. The case thus suggests that unless other objectives are put forward under s. 1, a failed ameliorative purpose argument will be fatal to the government under s. $1 .{ }^{170}$ In the end, the impugned sections of the MSA were declared unconstitutional and severed from the MSA, and the Registrar was directed to restore the claimants' names to the Peavine Métis Settlement’s membership list. ${ }^{171}$

\section{CONCLUSION}

It is remarkable that the Alberta Court of Appeal could deal with two s. 15 claims so differently in such a short time frame, and with one overlapping panel member. The difference is particularly noteworthy given that both cases involved discriminatory harms characterized as stereotyping. In our view, the Court applies no consistent or unified approach to s. 15 issues in Morrow and Cunningham. ${ }^{172}$ The same can be said for the diversity of approaches that other provincial courts of appeal have taken to claims of equality rights violations since the Supreme Court's decision in Kapp. ${ }^{173}$

Kapp left lower courts with little guidance, particularly on s. 15(1), and the Supreme Court's treatment of the equality claim in Ermineskin was perfunctory and did not provide sufficient elaboration. ${ }^{174}$ As we have argued, this is particularly true with respect to the role of comparators in the analysis, and the connection between comparators and grounds. ${ }^{175} \mathrm{~A}$ related problem is the Court's attempt to keep Law's contextual factors alive in Kapp, only to ignore them altogether in Ermineskin in favour of "the broader context." Here again the

admission of new evidence: see Cunningham v. Alberta (Minister of Aboriginal Affairs and Northern Development), 2009 ABCA 53, 446 A.R. 329.

169 Cunningham (C.A.), supra note 5 at paras. 66-70.

170 Kapp, supra note 1, made it clear that a program need only have an ameliorative goal as one of several objectives in order to qualify for s. 15(2) protection (at paras. 51-52). A court could therefore find that other, more majoritarian objectives might justify a violation of the equality guarantee even if its ameliorative purpose was not persuasive, or was not rationally implemented under s. 15(2).

171 Cunningham (C.A.), supra note 5 at para. 84. Section 25 of the Charter, supra note 2, which was raised by an intervener, was found to be inapplicable given the lack of an evidentiary basis for analyzing this section (which provides that Charter rights and freedoms "shall not be construed so as to abrogate or derogate from any aboriginal, treaty or other rights or freedoms that pertain to the aboriginal peoples of Canada”). This is unfortunate, as the case does raise important questions about the interaction between Métis rights of control over membership provided under the MSA, and individual membership rights. Benjamin Alarie \& Andrew James Green, in "Charter Decisions in the McLachlin Era: Consensus and Ideology at the Supreme Court of Canada," (2009) 47 Sup. Ct. L. Rev. (2d) 475, describe a style of appellate decision-making where each decision appears to be an isolated one as the "uncooperative" style. A cooperative style, on the other hand, sees appellate judges engaging in more collaborative, deliberate decision-making. They thus present a more consistent and unified Court of Appeal approach to discrete legal issues, clarifying the law for lower courts. The label "uncooperative" is not necessarily intended to be pejorative, depending on the reason for the lack of cooperation. Some judges value independence as the best method for achieving internally consistent reasoned decisions. Some Chief Justices encourage certain styles of interaction in the preparation of judgments. Sometimes, however, the lack of cooperation is due to ideological or personal differences. It usually takes a very large number of judgments before the reason becomes clear, with ideological or personal constraints on cooperation tending to lead to more plurality and dissenting judgments. See supra note 34.

174 The same could be said of the Supreme Court's approach to equality rights in Hutterian Brethren, supra note 65, and A.C., supra note 132.

175 In Morrow (C.A.), supra note 4 and Cunningham (C.A.), supra note 5 we also see little attention paid to comparator groups or to grounds of discrimination. 
Court is sending mixed signals about its intended approach and how that approach should be applied. The point on which the Court seems most clear — the definition of discrimination as the perpetuation of prejudice or stereotyping — is also problematic for the reasons discussed earlier in this article. In addition, the narrowness of the Court's understanding of discrimination wrongly suggests that all forms of discrimination are the same, that is, that racial, age, gender, disability, and other forms of discrimination can all be dealt with by understanding the harms of prejudice and stereotyping. ${ }^{176}$ The Court's failure to address the application of s. 15(2) to underinclusive ameliorative laws and programs may also undermine valid claims of discrimination.

While the Law test was seemingly far more determinative, however, it was malleable enough that the results in post-Law cases could not be predicted. ${ }^{177}$ It would appear that we may be in for another rather lengthy period of uncertainty in s. 15 jurisprudence.

On the other hand, it may be that the divergent outcomes in the three cases we examine here are not so much a question of what test was applied by the courts. While we have concerns with the focus on stereotyping and prejudice as the sole markers of discrimination, all three cases could have been resolved by finding stereotyping, a clearly recognized harm of discrimination according to any test. What seems most significant in the end is the court's ability to actually see the stereotyping at play in each case. ${ }^{178}$ This may ultimately have more to do with the nature of the inequalities at issue in each case, the individual judges' ability to understand those inequalities, or the adequacy of the facts and counsels' arguments, rather than the test a court applies. However, it is significant that none of the cases we examine sets out a definition of stereotyping, and it may be that such a definition would be useful in helping courts apply the concept. ${ }^{179}$

We recognize that some sort of "test" is important for litigators and the courts (not to mention law students and teachers trying to convey a very complex area), so what would we like the approach under s. 15 to look like? We believe that a return to Charter first principles would be most useful. If we are to remain within the constraints of a comparative approach, it should be sufficient for a s. 15 claimant to show differential treatment based on a protected ground that has the effect of causing discriminatory harm to them, whether through stereotyping, prejudice, disadvantage, vulnerability, oppression, denial of important benefits, or the like. As is the case for all other Charter rights, this should be a contextual analysis that considers the claimant's harms in broader social, historical, and political context. ${ }^{180}$ It should matter, for example, whether the claimant is a member of a historically disadvantaged group. Further, as is the case for all other Charter rights, unconstitutional effects of a law should be

For a similar argument, see Greschner, supra note 58 at 317.

Colleen Sheppard, "Constitutional Equality and Shifting Conceptions of the Role of the State: Obstacles and Possibilities,” in McIntyre \& Rodgers, supra note 14, 251 at 255, citing Lavoie v. Canada, 2002 SCC 23, [2002] 1 S.C.R. 769; Gosselin, supra note 147; Walsh, supra note 147.

Justices Ritter, Costigan, and McFadyen could see such stereotyping in Cunningham (C.A.), supra note 5 (although Shelley J. could not), while Rowbotham, O’Brien, and McFadyen JJ.A. could not see such stereotyping in Morrow (C.A.), supra note 4 (although Wittmann J. could). None of the justices sitting on the Supreme Court could see any stereotyping in Ermineskin, supra note 3.

For a useful definition of stereotyping see Moreau, supra note 44.

Turpin, supra note 33; R. v. Big M Drug Mart Ltd., [1985] 1 S.C.R. 295 at para. 117 [Big M Drug Mart]. 
sufficient to establish a breach, ${ }^{181}$ rather than requiring an unconstitutional purpose. It should be up to the government to justify its objectives under s. 15(2) or s. 1, and courts should not be overly deferential to governments at this stage. ${ }^{182}$ And, as the Court of Appeal held in Cunningham, Kapp should not bar the equality claims of disadvantaged groups merely because the law has an ameliorative purpose under s. 15(2). Where a disadvantaged group is wrongly excluded from ameliorative legislation — for instance, where the legislation discriminates through underinclusiveness - a s. 15(1) violation should be found. Overall, this is the sort of broad, purposive, and contextual approach that has been mandated for the analysis of protected rights and freedoms since the early days of the Charter, and there is no good reason it should not apply equally to equality rights. through unconstitutional purpose or effects of the law. See also Andrews, supra note 7. Cases involving the adverse impact of a law or program apparently neutral on its face appear to be difficult for courts to grasp. Most recently, see Hutterian Brethren, supra note 65. 


\section{APPENDix A}

\section{APPROACHES TO EqUALITY RIGHTS UNDER SECTION 15 OF THE CHARTER}

\begin{tabular}{|c|c|c|c|}
\hline Case & $\begin{array}{l}\text { Andrews } \\
\text { (SCC 1989) }\end{array}$ & $\begin{array}{l}\text { Law / Lovelace } \\
\text { (SCC 1999/2000) }\end{array}$ & $\begin{array}{l}\text { Kapp / Ermineskin } \\
\text { (SCC 2008/2009) }\end{array}$ \\
\hline $\begin{array}{l}\text { Test for } \\
\text { s.15(1) }\end{array}$ & $\begin{array}{l}\text { 1. Does the law create a } \\
\text { distinction based on an } \\
\text { enumerated or } \\
\text { analogous ground? } \\
\text { 2. Is the distinction } \\
\text { discriminatory? (at 180- } \\
\text { 81). } \\
\text { “[D]iscrimination may } \\
\text { be described as a } \\
\text { distinction, whether } \\
\text { intentional or not but } \\
\text { based on grounds } \\
\text { relating to personal } \\
\text { characteristics of the } \\
\text { individual or group, } \\
\text { which has the effect of } \\
\text { imposing burdens, } \\
\text { obligations, or } \\
\text { disadvantages on such } \\
\text { individual or group not } \\
\text { imposed upon others, or } \\
\text { which withholds or } \\
\text { limits access to } \\
\text { opportunities, benefits, } \\
\text { and advantages } \\
\text { available to other } \\
\text { members of society” (at } \\
\text { 174). }\end{array}$ & $\begin{array}{l}\text { 1. Does the law, in purpose or } \\
\text { effect: } \\
\text { (A) draw a formal distinction } \\
\text { between the claimant and } \\
\text { others based upon personal } \\
\text { characteristics, OR } \\
\text { (B) fail to take into account } \\
\text { the claimant's already } \\
\text { disadvantaged position within } \\
\text { Canadian society, resulting in } \\
\text { substantively differential } \\
\text { treatment between the } \\
\text { claimant and others on the } \\
\text { basis of one or more personal } \\
\text { characteristics? } \\
\text { 2. Is the differential treatment } \\
\text { based upon one or more } \\
\text { enumerated or analogous } \\
\text { grounds? } \\
\text { 3. Does the differential } \\
\text { treatment result in } \\
\text { "discrimination” by: } \\
\text { (A) imposing a burden upon } \\
\text { OR } \\
\text { (B) withholding a benefit } \\
\text { from the claimant in a manner } \\
\text { which violates the claimant's } \\
\text { essential human dignity? } \\
\text { (Law at para. 88) } \\
\text { A violation of human dignity } \\
\text { is to be assessed in light of } \\
\text { contextual factors, including: } \\
\text { (1) pre-existing disadvantage, } \\
\text { stereotyping, prejudice, or } \\
\text { vulnerability }\end{array}$ & $\begin{array}{l}\text { 1. Does the law create a } \\
\text { distinction based on an } \\
\text { enumerated or analogous } \\
\text { ground? } \\
\text { 2. Does the distinction } \\
\text { create a disadvantage by } \\
\text { perpetuating prejudice or } \\
\text { stereotyping? (Kapp at para. } \\
\text { 17; Ermineskin at para. } \\
\text { 188). } \\
\text { "The four factors cited in } \\
\text { Law are based on and relate } \\
\text { to the identification in } \\
\text { Andrews of perpetuation of } \\
\text { disadvantage and } \\
\text { stereotyping as the primary } \\
\text { indicators of discrimination. } \\
\text { Pre-existing disadvantage } \\
\text { and the nature of the } \\
\text { interest affected (factors } \\
\text { one and four in Law) go to } \\
\text { perpetuation of } \\
\text { disadvantage and prejudice, } \\
\text { while the second factor } \\
\text { deals with stereotyping. The } \\
\text { ameliorative purpose or } \\
\text { effect of a law or program } \\
\text { (the third factor in Law) } \\
\text { goes to whether the purpose } \\
\text { is remedial within the } \\
\text { meaning of s. 15(2). ... the } \\
\text { third Law factor might also } \\
\text { be relevant to the question } \\
\text { under s. 15(1) as to whether } \\
\text { the effect of the law or } \\
\text { program is to perpetuate }\end{array}$ \\
\hline
\end{tabular}




\begin{tabular}{|c|c|c|c|}
\hline Case & $\begin{array}{l}\text { Andrews } \\
\text { (SCC 1989) }\end{array}$ & $\begin{array}{l}\text { Law / Lovelace } \\
\text { (SCC 1999/2000) }\end{array}$ & $\begin{array}{l}\text { Kapp / Ermineskin } \\
\text { (SCC 2008/2009) }\end{array}$ \\
\hline $\begin{array}{l}\text { Test for } \\
\text { s.15(1) (con’t) }\end{array}$ & & $\begin{array}{l}\text { (2) correspondence between } \\
\text { ground(s) and the actual } \\
\text { need, capacity, or } \\
\text { circumstances of the claimant } \\
\text { or others } \\
\text { (3) ameliorative purpose or } \\
\text { effects of the impugned law } \\
\text { (4) nature and scope of the } \\
\text { interest affected by the } \\
\text { impugned law (Law at paras. } \\
\text { 62-75). } \\
\text { Harms of discrimination } \\
\text { include prejudice, } \\
\text { stereotyping, vulnerability, } \\
\text { powerlessness, oppression, } \\
\text { stigmatization, } \\
\text { marginalization, devaluation, } \\
\text { and disadvantage (Law at } \\
\text { paras. 29, 42, 44, 47, 53). }\end{array}$ & $\begin{array}{l}\text { disadvantage (Kapp, para. } \\
\text { 23). } \\
\text { "In determining whether } \\
\text { there is discrimination ... it } \\
\text { is important to look not } \\
\text { only at the impugned } \\
\text { legislation which has } \\
\text { created a distinction that } \\
\text { violates the right to equality } \\
\text { but also to the larger social, } \\
\text { political and legal context” } \\
\text { (Ermineskin at para. 193, } \\
\text { citing Turpin). }\end{array}$ \\
\hline $\begin{array}{l}\text { Comparator / } \\
\text { Grounds }\end{array}$ & $\begin{array}{l}\text { Equality "is a } \\
\text { comparative concept, } \\
\text { the condition of which } \\
\text { may only be attained or } \\
\text { discerned by } \\
\text { comparison with the } \\
\text { condition of others in } \\
\text { the social and political } \\
\text { setting in which the } \\
\text { question arises" (at } \\
\text { 164). }\end{array}$ & $\begin{array}{l}\text { “[A] court must identify } \\
\text { differential treatment as } \\
\text { compared to one or more } \\
\text { other persons or groups } \\
\text {... To locate the appropriate } \\
\text { comparator, we must consider } \\
\text { a variety of factors, including } \\
\text { the subject-matter of the } \\
\text { legislation.... Both the } \\
\text { purpose and the effect of the } \\
\text { legislation must be } \\
\text { considered in determining the } \\
\text { appropriate comparison } \\
\text { group or groups. Other } \\
\text { contextual factors may also } \\
\text { be relevant. The biological, } \\
\text { historical, and sociological } \\
\text { similarities or dissimilarities } \\
\text { may be relevant in } \\
\text { establishing the relevant }\end{array}$ & $\begin{array}{l}\text { Acknowledges the critique } \\
\text { that "the formalism of some } \\
\text { of the Court's post-Andrews } \\
\text { jurisprudence [has } \\
\text { resurfaced] in the form of } \\
\text { an artificial comparator } \\
\text { analysis focussed on } \\
\text { treating likes alike" (Kapp } \\
\text { at para. 22). }\end{array}$ \\
\hline
\end{tabular}




\begin{tabular}{|c|c|c|c|}
\hline Case & $\begin{array}{l}\text { Andrews } \\
\text { (SCC 1989) }\end{array}$ & $\begin{array}{l}\text { Law / Lovelace } \\
\text { (SCC 1999/2000) }\end{array}$ & $\begin{array}{l}\text { Kapp / Ermineskin } \\
\text { (SCC 2008/2009) }\end{array}$ \\
\hline $\begin{array}{l}\text { Comparator / } \\
\text { Grounds } \\
\text { (con't) }\end{array}$ & & $\begin{array}{l}\text { comparator in particular, and } \\
\text { whether the legislation effects } \\
\text { discrimination in a } \\
\text { substantive sense more } \\
\text { generally" (Law at paras. 56- } \\
\text { 57). }\end{array}$ & \\
\hline $\begin{array}{l}\text { Test for } \\
\text { s.15(2) }\end{array}$ & $\begin{array}{l}\text { "[T]he fact that } \\
\text { identical treatment may } \\
\text { frequently produce } \\
\text { serious inequality is } \\
\text { recognized in s.15(2)" } \\
\text { (at 171). }\end{array}$ & $\begin{array}{l}\text { Section } 15(2) \text { "acts as an } \\
\text { interpretive aid to s. 15(1)" } \\
\text { and is "confirmatory of s. } \\
\text { 15(1)" rather than having } \\
\text { independent force. However, } \\
\text { "we may well wish to } \\
\text { reconsider this matter at a } \\
\text { future time in the context of } \\
\text { another case” (Lovelace at } \\
\text { paras. 106,108). }\end{array}$ & $\begin{array}{l}\text { "A program does not } \\
\text { violate the s. } 15 \text { equality } \\
\text { guarantee if the government } \\
\text { can demonstrate that: (1) } \\
\text { the program has an } \\
\text { ameliorative or remedial } \\
\text { purpose; and (2) the } \\
\text { program targets a } \\
\text { disadvantaged group } \\
\text { identified by the } \\
\text { enumerated or analogous } \\
\text { grounds” (Kapp at para. } \\
\text { 41). }\end{array}$ \\
\hline Section 1 & $\begin{array}{l}\text { "Where discrimination } \\
\text { is found a breach of s. } \\
15(1) \text { has occurred and } \\
\text { — where s. 15(2) is not } \\
\text { applicable - any } \\
\text { justification, any } \\
\text { consideration of the } \\
\text { reasonableness of the } \\
\text { enactment; indeed, any } \\
\text { consideration of factors } \\
\text { which could justify the } \\
\text { discrimination and } \\
\text { support the } \\
\text { constitutionality of the } \\
\text { impugned enactment } \\
\text { would take place under } \\
\text { s. 1" (at 182). }\end{array}$ & $\begin{array}{l}\text { No s. } 1 \text { analysis in either } \\
\text { case. }\end{array}$ & $\begin{array}{l}\text { Section } 1 \text { analysis } n / a \text { in } \\
\text { both cases. }\end{array}$ \\
\hline
\end{tabular}

